\title{
IMMIGRATION IN ITALY BETWEEN FIRST AND SECOND REPUBLIC. FROM THE RECEPTION POLICIES TO THE «EMERGENCY» MANAGEMENT OF MIGRATIONS (1980-2018)
}

\author{
LA INMIGRACIÓN EN ITALIA ENTRE LA PRIMERA Y LA SEGUNDA \\ REPÚBLICA. DE LAS POLÍTICAS DE ACOGIDA A LA GESTIÓN \\ «DE EMERGENCIA»DE LAS MIGRACIONES (1980-2018)
}

\author{
Luigi Chiara*, Francesca Frisone
}

Università degli Studi di Messina. Italia

\begin{abstract}
This paper aims to analyze the Italian migration policies of the last thirty years by using statistical data. We would like to underline how these policies are not related to the actual arrivals, and how the Italian governments looked at this phenomenon, mostly, as a threat to public order. It is possible to highlight a first phase (1980-1990), during which laws are «exceptional» or administrative acts aimed to manage the foreigners incoming and their rights related to the job market needs. A second phase (1990-2001), with a more systematic framework for migration management; a third phase (2002-2011), during which laws have been changed in a more restrictive and repressive sense. Since 2011 the fast changes in Middle East and Arab world have triggered new arrivals across the Mediterranean and the populist government elected in 2018, launched a new decree that restricts the possibilities to accept asylum seekers.
\end{abstract}

KEYWORDS: migration policies, Italian history, Mediterranean, asylum.

RESUMEN: Este artículo analiza las políticas migratorias italianas de los últimos treinta años utilizando datos estadísticos, con el fin de señalar cómo estas políticas no están relacionadas con la realidad de las llegadas y cómo los gobiernos italianos han considerado este fenómeno, sobre todo, una amenaza para el orden público. Es posible indicar una primera fase (1980-1990) en la que los actos administrativos gestionan la llegada de los extranjeros y su regularización, respecto a las exigencias del mercado laboral; una segunda (1990-2001), con un marco más sistemático para la gestión de la inmigración; una tercera (2002-2011), en la que las leyes fueron modificadas en un sentido más restrictivo. Desde 2011 la rapidez de los cambios en Oriente Medio y en el mundo árabe provocaron nuevas llegadas en todo el Mediterráneo, y el gobierno populista elegido en 2018 puso en marcha un nuevo decreto que limita las posibilidades de aceptar solicitantes de asilo.

PALABRAS CLAVE: política migratoria, Historia italiana, Mediterráneo, asilo.

* Correspondence to: Luigi Chiara. Università degli Studi di Messina, Dipartimento di Scienze Politiche e Giuridiche, Piazza XX Settembre, 4 - 98122 Messina (Italy)- Ichiara@unime.it - https://orcid.org/0000-0001-6519-7631

How to cite: Chiara, Luigi; Frisone Francesca (2021). "Immigration in Italy between First and Second Republic. From the Reception Policies to the "Emergency" Management of Migrations (1980-2018)»; Historia Contemporánea, 65, 233-274. (https://doi.org/10.1387/hc.20941).

Received: 19 julio, 2019; Accepted: 15 noviembre, 2019.

ISSN 1130-2402 - elSSN 2340-0277 / C 2020 UPV/EHU

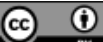

This article is distributed under the terms of the

Creative Commons Atribution 4.0 Internacional License 


\section{Premise}

Mobility within national borders, as well as outside them, was constant throughout the $19^{\text {th }}$ and the $20^{\text {th }}$ centuries, as demonstrated by the huge scientific literature on migration ${ }^{1}$ and the equally sizeable statistics available to scholars, although for some periods they are definitely incomplete $^{2}$.

Beyond the inaccuracy of the data, which must always be taken into account, the numbers concerning the Italian population «on the move» give an overall picture of high attitude for displacements, of short or long term ${ }^{3}$.

In the same way, it is also possible to detect a sort of permeability of the Italian society to foreign communities grafts, which have contributed to the slow and progressive modernisation of the country, triggered also due to the different socio-cultural contaminations and to the importation of economic and political models that occurred with particular intensity in the first half of the $19^{\text {th }}$ century ${ }^{4}$. However, this permeability has become more problematic in the second part of the $20^{\text {th }}$ century, when the country became an immigration country. Decrease of emigration has been activated, in conjunction with the economic growth experienced by Italy at the end of the 1950s, which, along with more general demographic and political-social factors ${ }^{5}$, contributed to

1 The Premise, and the paragraphs 1,2 and 3 are written by Luigi Chiara. The paragraphs 4 e 5 are written by Francesca Frisone. The Conclusion is written by the authors. For an overview, see Bevilacqua, De Clementi, Franzina, 2001; Idd., 2002, and the bibliography therein contained.

${ }^{2}$ We refer to the absence of specific data about the pre-unification period, as well as to the inaccuracy of the same data, collected «according to the scientific method and [...] with appropriate tools» by the Statistical Board from 1876. Rinauro, 2010; Ostuni, Rosoli, 1978; Franzina, 1980.

3 Take into account periodic migrations towards the coast, or from the countryside to the cities, and towards North-European or North-African destinations; Corti, 2001; Villani, 1986.

${ }^{4}$ For some notes on foreign communities settlement, particularly in the case of the South and in Sicily, D'Angelo, 1995; Banti, 1989; Salvemini, 1984. On circulation of political models, Rosselli, 2002; Novarese, 2005.

${ }^{5}$ We refer, briefly: to the demographic trend, the reduction of the birth rate and the progressive orientation towards the mononuclear family; to the general increase of per capita income and of GDP, which also determined a change in employment expectations and the emergence of new spaces in the labour market for professions «rejected» by skilled labour, now prerogative of foreigners, such as domestic workers (African, Filipino or Cape Verdean, employed by wealthy families). A proportion of foreigners was also due to the presence of the first communities of university students. Bontempelli, 2009 and Einaudi, 2007, p. 84. 
Immigration in Italy between First and Second Republic. From the Reception Policies...

define the new mobility patterns of Italians within the peninsula (but not exclusively) ${ }^{6}$.

This positive situation, which underwent a first slowdown at the beginning of the 1960s, would not be enough to explain the simultaneous increase, in this years, in the number of foreign inflow in Italy ${ }^{7}$. It was a new trend, which became more systematic around the second half of the 1970s, and showed connection to the articulated dynamics of the national and international labor market ${ }^{8}$.

Moreover, between the 1970s and 1980s, the great migrations from Third World countries have been added to the traditional mobility which had historically characterized migrations from European countries, mainly oriented towards the countries belonging to North America and Europe.

During this period countries that had traditionally lost population for a strong emigration, such as Italy or Spain, started becoming immigration areas. It is a kind of immigration that first involves the area of the North African countries (particularly the countries of the Maghreb area), to which have to be added the 1990s new arrivals from Albania, China and - after the year 2000 - from Eastern Europe countries. In this context, also the number of illegal immigrants and refugees for political reasons is gradually increasing.

Summarising, over the past two decades, the geography of departures has deeply changed. For instance, we can see the official statistical data about applications for residency permits: at the beginning of the 1990 s, Africa was by far the first continent of origin of foreigners having a residency permit (over a third of the residents in Italy came from an African country). Twenty years later, only a fifth of the residents are

${ }^{6}$ From the southern to northern regions, which began to need, and host, cheap labour. See Casacchia, Natale, Strozza, 1999. Destinations also change, now oriented more towards Europe and less towards America.

${ }^{7}$ Foreigners residing in our country around the 1960s were mostly students, political exiles and migrants returning from African colonies. See ISTAT data for the years 1947-48 (1.014 students), and 1969-1970 (12.035 students); Einaudi, 2007, p. 84.

${ }^{8}$ For the so called push factors, see Venturini, 2001, p. 40. Furthermore, most of the European countries traditionally affected by large volumes of arrivals faced the «global» recessionary phase triggered by the oil shock, among other things, with the launch of severe measures to block the entrances, causing a redistribution of the number of migrants to new destinations. However, the most recent studies seem to reduce the weight of these «closure» policies with respect to Italy, which had already become «autonomous destination in the immigration systems» before the Kippur crisis; see Colombo, Sciortino, 2004, p. 54. On the economic factors which determine the repositioning of Italy among the first-choice destinations, see Einaudi, 2007, p. 59 and ss; Bade, 2001; Hatton, Williamson (ed.), 1994, pp. 72-90. 
from the Dark Continent, while the absolute majority of foreign residents (over 50\%) had European origins. But the demographic projections, as well as the analysis of the global trends about demographic and economic disorders, already suggest for the future, a consistent recovery of migratory flows from Africa and Asia towards Italy and European countries.

\section{Foreigners distribution within the country}

In the period between the 1980s and the first census of 2011, the number of immigrants living in Italy — which can be extracted through the censuses of the population carried out by Istat - increases in a very considerable way. There are significant differences between the two main periods analysed, 1981-2001, and 2011-2018. In the first period, the totals related to regular immigration recorded not too high amounts, overall reaching, in $1981, \mathbf{2 1 0 . 9 3 7}$ units (around $0,4 \%$ of the resident population), which became 356.159 in 1991 and $\mathbf{1 . 3 3 4 . 8 8 9}$ in 2001 (both 0,6\% and $2,3 \%$ of the population). This is a truly impressive progression, since already 10 years after 2001 the immigrants reaches over $\mathbf{4}$ million people, reaching slightly over 5 million in 2014, to remain stable until $1^{\text {st }}$ January 2018 (5.144.440 units).

Looking at the two periods, it is possible to notice how the composition changes according to age of the immigrant population: the proportion of immigrants aged 65 and over, which in 1981 is $10,5 \%$ of the total of the groups, progressively decreases, and in 2014 it is reduced to $3 \%$. See how this flow of migrants is distributed within the Italian regions and in the various provinces, limiting the comparison to the period after 2001, considering that, up to that year, the number of immigrant residents has fairly contained totals. The balances relating to foreigners residing in Italy in the period after 2011 and until 2017 are very different, years during which the foreign population grows massively, reaching 7\% (2011) and 8\% (2017) of the total of resident population in Italy. 
Immigration in Italy between First and Second Republic. From the Reception Policies...

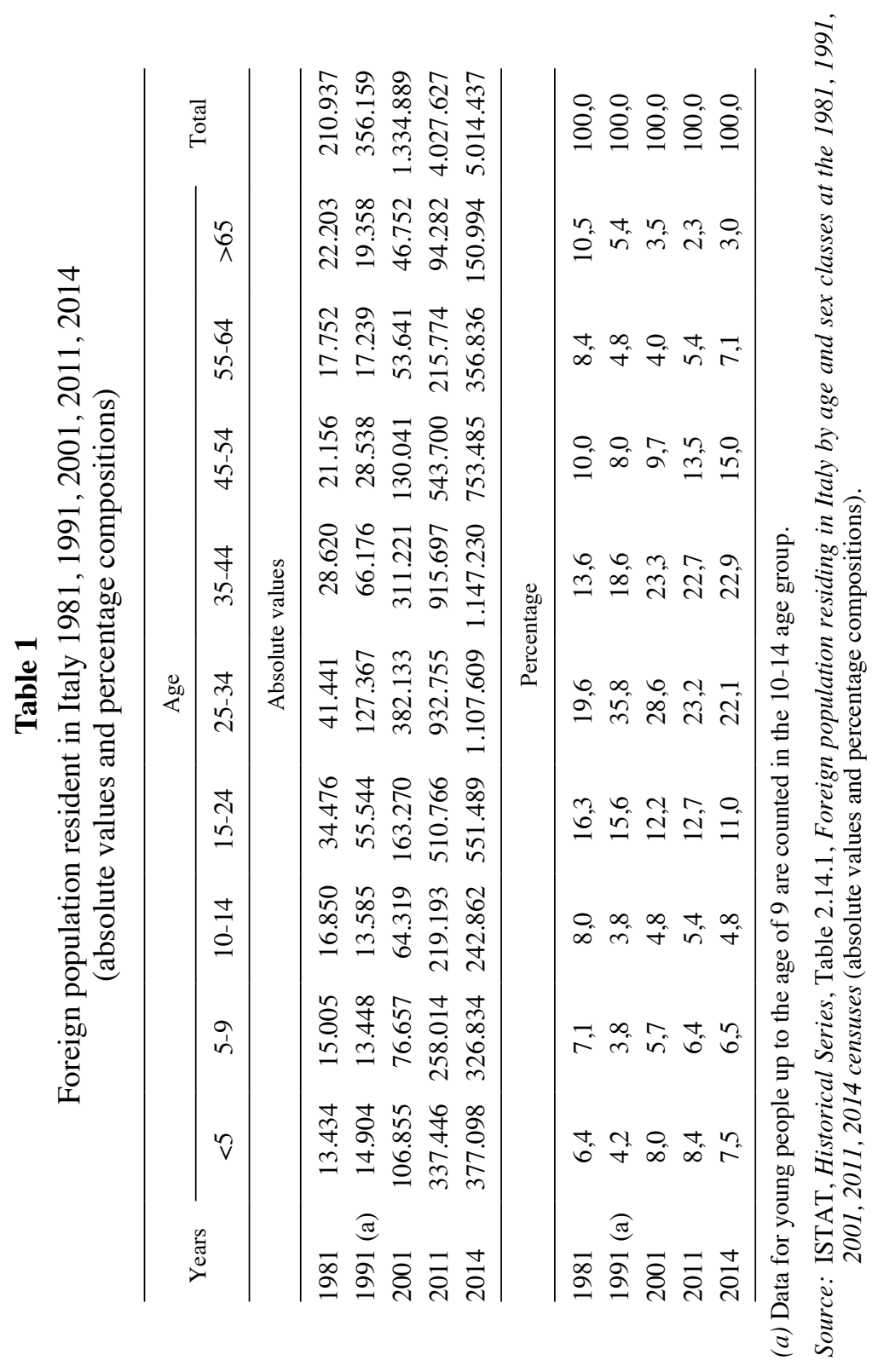

https://doi.org/10.1387/hc.20941 


\section{Table 2}

Foreigners by regions (2011-2017)

\begin{tabular}{|c|c|c|c|c|c|c|c|}
\hline Region & 2011 & 2012 & 2013 & 2014 & 2015 & 2016 & 2017 \\
\hline Italy & 4.027 .627 & 4.052 .081 & 4.387 .721 & 4.922 .085 & 5.014 .437 & 5.026 .153 & 5.047 .028 \\
\hline Piedmont & 359.348 & 384.996 & 425.523 & 425.448 & 425.448 & 422.027 & 418.874 \\
\hline Valle d'Aosta & 8.419 & 9.148 & 9.333 & 9.075 & 9.075 & 8.480 & 8.257 \\
\hline Liguria & 111.416 & 119.946 & 138.355 & 138.697 & 138.697 & 136.216 & 138.324 \\
\hline Lombardy & 947.288 & 1.028 .663 & 1.129 .185 & 1.152 .320 & 1.152 .320 & 1.149 .011 & 1.139 .463 \\
\hline $\begin{array}{l}\text { Trentino Alto } \\
\text { Adige South } \\
\text { Tyrol }\end{array}$ & 85.100 & 91.047 & 96.302 & 96.149 & 46.045 & 46.454 & 46.794 \\
\hline Bolzano & 39.396 & 42.337 & 45.469 & 46.045 & 46.045 & 46.454 & 46.794 \\
\hline Veneto & 457.328 & 487.030 & 514.592 & 511.558 & 511.558 & 497.921 & 485477 \\
\hline $\begin{array}{l}\text { Friuli-Venezia } \\
\text { Giulia }\end{array}$ & 96.879 & 102.568 & 107.917 & 107.559 & 107.559 & 105.222 & 104.276 \\
\hline Emilia-Romagna & 452.036 & 488.489 & 534.308 & 536.747 & 536.747 & 533.479 & 529.337 \\
\hline Tuscany & 321.847 & 350.761 & 387.350 & 395.573 & 395.573 & 396.219 & 400.370 \\
\hline Umbria & 87.715 & 92.794 & 99.922 & 98.618 & 98.618 & 96.875 & 95.935 \\
\hline Marche & 133.207 & 139.800 & 146.152 & 145.130 & 145.130 & 140.341 & 136.199 \\
\hline Lazio & 425.707 & 477.544 & 616.406 & 636.524 & 636.524 & 645.159 & 662.927 \\
\hline Abruzzo & 68.091 & 74.939 & 84.285 & 86.245 & 86.245 & 86.363 & 86.556 \\
\hline Molise & 8.023 & 9.110 & 10.268 & 10.800 & 10.800 & 12.034 & 12.982 \\
\hline Campania & 148.119 & 170.938 & 203.823 & 217.503 & 217.503 & 232.214 & 243.694 \\
\hline Apulia & 82.680 & 96.131 & 110.338 & 117.732 & 117.732 & 122.724 & 127.985 \\
\hline Basilicata & 12.928 & 14.728 & 16.968 & 18.210 & 18.210 & 19.442 & 20.783 \\
\hline Calabria & 65.809 & 74.069 & 86.491 & 91.354 & 91.354 & 96.889 & 102.824 \\
\hline Sicily & 125.015 & 139.410 & 162.408 & 174.116 & 174.116 & 183.192 & 189.169 \\
\hline Sardinia & 30.672 & 35.610 & 42.159 & 45.079 & 45.079 & 47.425 & 50.346 \\
\hline
\end{tabular}

Source: ISTAT, Historical Series, Table 2.14.1, Foreign population residing in Italy by age, gender and region at the 1981, 1991, 2001, 2011, 2014 censuses (absolute values); ISTAT, Survey of the foreign municipal resident population by sex and year of birth. 
These flows of foreigners are divided between the Italian regions according to a geography that seems to support, on the one hand, the different potentialities and economic vocations of the territories, and on the other, the traditional lines of historical settlement. Nonetheless, here it would be interesting to carry out even an analysis of internal flows, that is of the migrant population balances within the Italian regions, but that would move our reflections to another observation plan, although looking at the data, it seems that in the medium term the tendency is the consolidation of the original settlements, due in part to the reunification and the natural increases in births. The analysis of data relating to the period between 2011 and 2017 shows a distribution of residents of foreign origin among the Italian regions which, in 2017, places Lombardy in the first place (1.139.463) and just after Lazio (662.927), Emilia Romagna (529.337), Veneto (485.477), Piedmont (418.874), Tuscany (400.370), Campania (243.694), and Sicily (189.169).

These are the 8 most populous regions of Italy that together receive over $80 \%$ of foreigners living in Italy, within which it is possible to record the greatest increases in the foreign population, particularly between 2011 and 2017, in Lazio (237.220), Lombardia (192.175) and Campania (95.575), which together represent more than half $(51 \%)$ of the overall increase (1.019.401).

It is also observed that the resident foreigners are distributed more predominantly in the regional provincial county towns, placing the province of Rome in first place among those that host, in 2017, the largest number of them (544.956). 


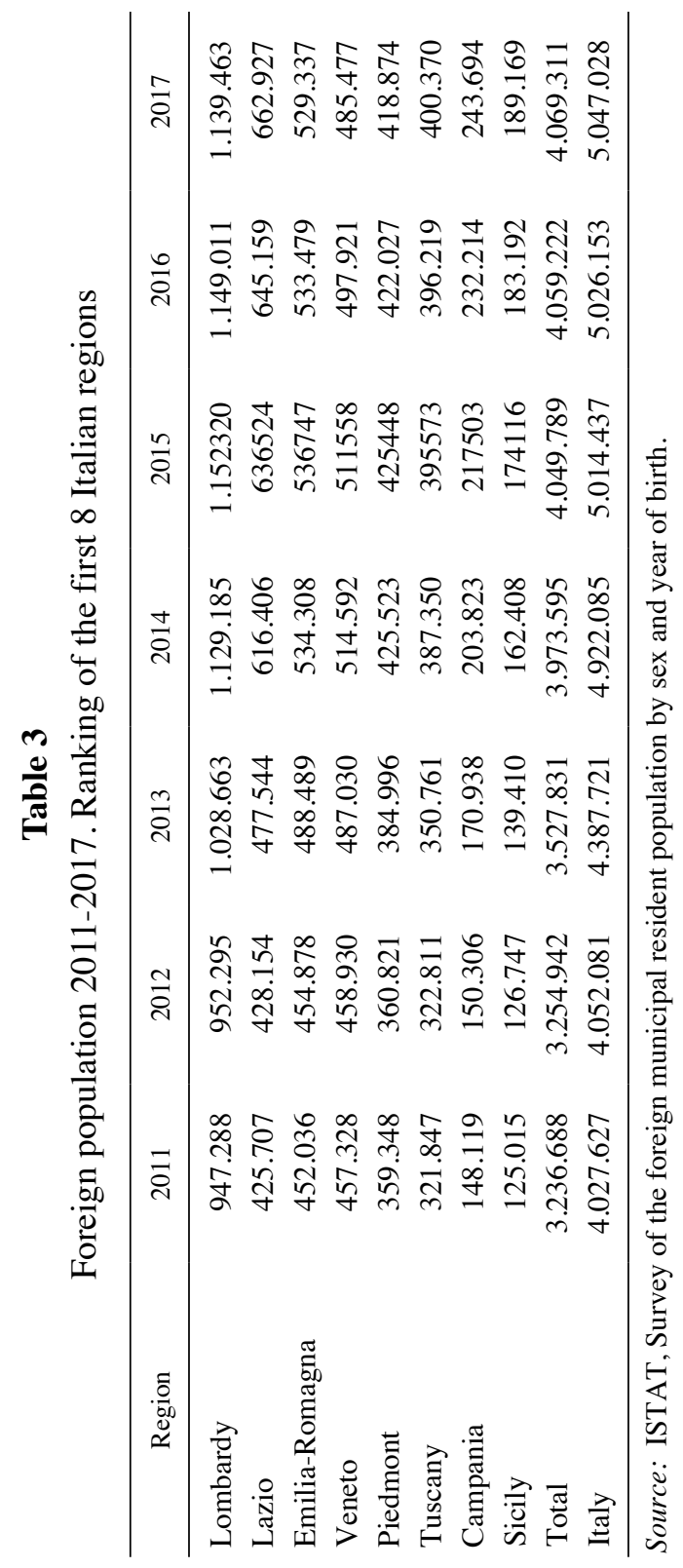


Immigration in Italy between First and Second Republic. From the Reception Policies...

\section{Table 4}

Foreign population 2011-2017. Ranking of the first 8 regions.

Distribution by province

\begin{tabular}{lrrrrrrr}
\hline \multicolumn{1}{c}{ Region } & \multicolumn{1}{c}{2011} & \multicolumn{1}{c}{2012} & \multicolumn{1}{c}{2013} & \multicolumn{1}{c}{2014} & \multicolumn{1}{c}{2015} & \multicolumn{1}{c}{2016} & \multicolumn{1}{c}{2017} \\
\hline Lombardy & 947.288 & 952.295 & 1.028 .663 & 1.129 .185 & 1.152 .320 & 1.149 .011 & 1.139 .463 \\
Milan & 324.378 & 324.749 & 358.321 & 416.137 & 439.308 & 446.462 & 446.923 \\
Lazio & 425.707 & 428.154 & 477.544 & 616.406 & 636.524 & 645.159 & 662.927 \\
Rome & 342.686 & 344.244 & 383.464 & 508.241 & 523.957 & 529.398 & 544.956 \\
Emilia- & 452.036 & 454.878 & 488.489 & 534.308 & 536.747 & 533.479 & 529.337 \\
Romagna & & & & & & & \\
Bologna & 94.163 & 945.38 & 105.287 & 113.367 & 115.809 & 117.122 & 117.861 \\
Veneto & 457.328 & 458.930 & 487.030 & 514.592 & 511.558 & 497.921 & 485.477 \\
Verona & 94.340 & 94.464 & 100.891 & 109.471 & 109.768 & 107.049 & 104.842 \\
Piedmont & 359.348 & 360.821 & 384.996 & 425.523 & 425.448 & 422.027 & 418.874 \\
Turin & 183.178 & 183.071 & 195.806 & 222.419 & 222.744 & 221.961 & 219.034 \\
Tuscany & 321.847 & 322.811 & 350.761 & 387.350 & 395.573 & 396.219 & 400.370 \\
Florence & 97.071 & 97.395 & 109.721 & 122.272 & 126.694 & 128.509 & 129.740 \\
Campania & 148.119 & 150.306 & 170.938 & 203.823 & 217.503 & 232.214 & 243.694 \\
Naples & 70.459 & 71.142 & 82.756 & 102.460 & 108.751 & 117.825 & 123.733 \\
Sicily & 125.015 & 126.747 & 139.410 & 162.408 & 174.116 & 183.192 & 189.169 \\
Palermo & 26.807 & 27.083 & 29.212 & 32.982 & 35.609 & 36.980 & 37.200 \\
\hline
\end{tabular}

Source: ISTAT, Censuses of the foreign municipal resident population by sex and year of birth.

\section{The home countries}

Let us now turn to the analysis of migration flows, highlighting their distribution according to the different countries of origin. First of all, it should be pointed out that in 1981 it was still a resident population which, for the most part, comes from Western European countries, and particularly from France (10,9\%), Germany (7\%), and England ( 5,3\%), compared to a population from North African countries, mostly composed of Tunisians $(3,9 \%)$ and Moroccans $(0,5 \%)$. If we try to add to the population that comes from Western Europe, the one coming from United States $(8,8 \%)$ we arrive to a $32 \%$ of the entire resident foreign population. This is a percentage destined, over the years, and in the me- 
dium/long term, to be drastically reduced, falling to $2,1 \%$ in 2014: being a resident population which did not arrive in Italy because of economic problems, but mostly to occupy jobs of medium-high level, it must be concluded that Italy has lost part of its appeal, giving away new graduates and professionals, mostly young and coming from the southern regions, who to an ever more considerable extent move abroad.

Already in the 1991 census it is possible to highlight how, to the community of foreigners coming from Morocco and Tunisia - which has grown respectively to $11,2 \%$ and to $4,7 \%$ of the total residents -, a large population joined from ex-Yugoslavia (4,8\%) and Philippines (4,3\%), but also from Albania (3\%) and China $(2,1 \%)$. Only ten years later, that is at the following 2001 population census, foreigners from Albania rose to $13 \%$. To them it is necessary to add the other more numerous communities coming from the eastern countries, ex-Yugoslavia $(3,7 \%)$, Romania $(5,6 \%)$ and Poland (2\%): that means $24,3 \%$ of the entire resident foreign population, while the other more numerous communities are still represented by Morocco $(13,5 \%)$, Tunisia $(3,6 \%)$, China $(3,5 \%)$ and Senegal $(2,3 \%)$. Things still change more decisively at the 2011 census: the Romanian community surpasses all others, reaching $20,4 \%$ and more generally, the area representing the Eastern Europe countries, Albania in the first place $(11,2 \%)$ is strengthened. Then, there are Moldova, Poland and Ukraine $(9,7 \%$ overall), to which other more numerous communities from China (4,8\%), Morocco (10,1\%), Tunisia (2\%) and Senegal (1,8\%) should be added, these last decreased in size. It is also worth noting the substantial growth of the Filipino community, which rose from $0,7 \%$ in 1981 to $3,2 \%$ in 2011; and the growth of the Indian community, which from $1,2 \%$ in 1991, rises to $2,9 \%$ in 2011 .

So, between 1991 and 2011, after the fall of the Berlin Wall and the end of the communist regimes, throughout the 1990s the presence of Eastern Europe strengthened and the trend continued at the top of the years 2000s: at the beginning of the 1990s, Africa was the first continent to be represented, 20 years later only 1/5 of foreign residents in Italy is originally from an African country, while the absolute majority (53\%) is of European origins. Between 2011 and 2017 the number and the composition of the resident foreign population tends to change also due to the processes that have destabilized the countries of the North African area (the Arab springs) and the Middle East (terrorism), although it remains within the previous traditional migratory lines and, as it is logical, from the census data point of view, it is necessary to wait, to better evaluate further elements of change 
of the «derived» communities some more years. Still on $1^{\text {st }}$ January 2018, however, in the first place among the top 20 communities resident in Italy we find Romania with 1.190.091 residents to which we have to add Albania (440.465), Ukraine (237.047), Moldova (131.814) and Poland (95.727): there are over 2.000 .000 people out of a total number of residents which amounts to just over 5.000.000 people and to whom it is possible to add the population from the other Eastern Europe countries to reach almost half of the entire foreign population residing in Italy.

\section{Table 5}

Foreigners resident in Italy according to the main citizenships at the 1981, 1991, 2001, 2011 and December 31 ${ }^{\text {st }}, 2012,2013$ and 2014 censuses (percentage compositions)

\begin{tabular}{lcrrrrrr}
\hline & 1981 & 1991 & 2001 & 2011 & 2012 & 2013 & 2014 \\
\hline Albania & $\ldots$ & 3,0 & 13,0 & 11,2 & 10,6 & 10,1 & 9,8 \\
China & $\ldots$ & 2,1 & 3,5 & 4,8 & 5,1 & 5,2 & 5,3 \\
Ex-Jugoslav. (a) & 2,4 & 4,8 & 3,7 & 1,1 & 4,9 & 4,6 & 4,4 \\
Philippines & 0,7 & 4,3 & 4,0 & 3,2 & 3,2 & 3,3 & 3,4 \\
France & 10,9 & 4,4 & 2,2 & 0,6 & 0,6 & 0,6 & 0,6 \\
Germany & 7,0 & 6,4 & 2,6 & 0,9 & 0,8 & 0,8 & 0,7 \\
India & $\ldots$ & 1,2 & 2,0 & 2,9 & 2,9 & 2,9 & 2,9 \\
Morocco & 0,5 & 11,2 & 13,5 & 10,1 & 9,7 & 9,2 & 9,0 \\
Moldova & $\ldots$ & $\ldots$ & 0,3 & 3,2 & 3,2 & 3,0 & 2,9 \\
Poland & $\ldots$ & 1,6 & 2,0 & 2,1 & 2,0 & 2,0 & 2,0 \\
United Kingdom & 5,3 & 3,9 & 1,5 & 0,6 & 0,5 & 0,5 & 0,5 \\
Romania & $\ldots$ & 2,7 & 5,6 & 20,4 & 21,3 & 22,0 & 22,6 \\
Senegal & $\ldots$ & 3,0 & 2,3 & 1,8 & 1,8 & 1,8 & 1,9 \\
Tunisia & 3,9 & 4,7 & 3,6 & 2,0 & 2,0 & 2,0 & 1,9 \\
Ukraine & $\ldots$ & $\ldots$ & 0,6 & 4,4 & 4,4 & 4,5 & 4,5 \\
USA & 8,8 & 4,2 & 1,3 & 0,3 & 0,3 & 0,3 & 0,3 \\
Peru & $\ldots$ & 0,9 & 2,2 & 2,3 & 2,3 & 2,2 & 2,2 \\
Others & 60,4 & 41,7 & 35,9 & 27,9 & 24,4 & 25,0 & 25,2 \\
\hline Total & 100 & 100 & 100 & 100 & 100 & 100 & 100 \\
\hline
\end{tabular}

(a) Serbia, Kosovo, Montenegro, Croatia, Slovenia, Bosnia and Herzegovina, Ex-Jugoslavia, Republic of Macedonia.

Source: ISTAT, Table 2.15 - Foreigners residing in Italy according to the main citizenships at the 1981, 1991, 2001, 2011 and December 31 2012, 2013 and 2014 censuses (absolute values and percentage compositions) 
About nationalities, we find China (290.681 which in 2011 had 194.510 residents) preceded by the Moroccan community (now 416.531, in 2011 407.097) and the traditional settlements of the following nationalities: Filipino, Indian, and Sri Lankan, with very noticeable increases of Egypt, Pakistan, Senegal, Tunisia and Nigeria, which rank among the top 20 most numerous nationalities in Italy. The first 20 positions in the two periods between 2011 and 2018 are detailed below.

Non-EU citizens on $1^{\text {st }}$ January 2018 amounted to around 3.7 million residents, while the top 20 nations representing the largest communities in both years accounted for around $80 \%$ of the entire resident foreign population.

\section{Table 6}

Continents of origin on 1st January 2018

\begin{tabular}{lrrrr}
\hline & \multicolumn{1}{c}{ Men } & \multicolumn{1}{c}{ Women } & \multicolumn{1}{c}{ Total } & \multicolumn{1}{c}{$\%$} \\
\hline Europe & 1.070 .862 & 1.549 .395 & 2.620 .257 & $50,93 \%$ \\
Africa & 673.573 & 422.516 & 1.096 .089 & $21,31 \%$ \\
Asia & 583.231 & 470.607 & 1.053 .838 & $20,48 \%$ \\
America & 142.788 & 228.566 & 371.354 & $7,22 \%$ \\
Oceania & 891 & 1.279 & 2.170 & $0,04 \%$ \\
Stateless people & 377 & 355 & 732 & $0,01 \%$ \\
$(*)$ & & & & 100 \\
\hline Total & & & & \\
\hline
\end{tabular}

Source: ISTAT, Movement and calculation of the resident foreign population and structure by citizenship, Acquisitions of citizenship: Main countries of citizenship http://dati. istat.it/Index.aspx?QueryId=19103. 
Immigration in Italy between First and Second Republic. From the Reception Policies...

Table 7

Ranking of the first 20 nations on $1^{\text {st }}$ January 2018

\begin{tabular}{|c|c|c|}
\hline \multicolumn{3}{|c|}{2018} \\
\hline & & $\%$ \\
\hline Romania & 1.190 .091 & 23,13 \\
\hline Albania & 440.465 & 8,56 \\
\hline Morocco & 416.531 & 8,10 \\
\hline China & 290.681 & 5,65 \\
\hline Ukraine & 237.047 & 4,61 \\
\hline Philippines & 167.859 & 3,26 \\
\hline India & 151.791 & 2,95 \\
\hline Bangladesh & 131.967 & 2,57 \\
\hline Moldova & 131.814 & 2,56 \\
\hline Egypt & 119.513 & 2,32 \\
\hline Pakistan & 114.198 & 2,22 \\
\hline Sri Lanka & 107.967 & 2,10 \\
\hline Nigeria & 106.069 & 2,06 \\
\hline Senegal & 105.937 & 2,06 \\
\hline Peru & 97.379 & 1,89 \\
\hline Poland & 95.727 & 1,86 \\
\hline Tunisia & 93.795 & 1,82 \\
\hline Ecuador & 80.377 & 1,56 \\
\hline Macedonia & 65.347 & 1,27 \\
\hline Bulgaria & 59.254 & 1,15 \\
\hline Total & 4.203 .809 & 81,7 \\
\hline Total for other countries & 940.631 & 18,3 \\
\hline Total foreign pop. & 5.144 .440 & 100 \\
\hline
\end{tabular}

Source: ISTAT, Movement and calculation of the resident foreign population and structure by citizenship, Acquisitions of citizenship: Main countries of citizenship, http:// dati.istat.it/Index.aspx?QueryId=19103 


\section{About employment status}

Finally, and without any claim of completeness, considering that going into detail on the employment condition would require a separate analysis, it is generally possible to observe how the majority of the foreign population is distributed mainly in the sector of services and construction that together, in the period between 2002 and 2010, occupy the majority of males aged 15 or over, with different percentages depending on the geographical areas considered.

Along the professional condition, even making a comparison between 2011 and 2017, it is mostly about unskilled personnel, whose percentages, also in this case, change according to the geographical areas considered and the economic and social context referred to.

\section{Table 8}

Male foreign citizens employed by professional status 15 -year-old males and older (data are expressed in thousands)

\begin{tabular}{llrrrrrr}
\hline Territory & 2005 & 2006 & 2007 & 2008 & 2009 & 2010 \\
\hline \multirow{4}{*}{ Italy } & Total & 711 & 793 & 870 & 992 & 1.026 & 1.087 \\
& Agriculture, hunting and fishing & 41 & 39 & 39 & 46 & 56 & 61 \\
& Industry total & 395 & 452 & 502 & 573 & 586 & 610 \\
& Industry total excluding & 225 & 235 & 263 & 303 & 300 & 303 \\
& construction & & & & & & \\
& Constructions & 170 & 217 & 239 & 270 & 285 & 307 \\
& Services total & 274 & 302 & 329 & 373 & 385 & 416 \\
& Trade, hotels and restaurants & 117 & 142 & 147 & 168 & 176 & 187 \\
& Other services activities & 157 & 160 & 182 & 205 & 208 & 229 \\
\hline \multirow{4}{*}{ North } & Total & 478 & 534 & 580 & 668 & 672 & 690 \\
& Agriculture, hunting and fishing & 16 & 17 & 17 & 21 & 23 & 22 \\
& Industry total & 303 & 331 & 359 & 411 & 412 & 415 \\
& Industry total excluding & 187 & 193 & 213 & 241 & 237 & 236 \\
& construction & & & & & & \\
& Constructions & 116 & 138 & 146 & 169 & 174 & 179 \\
& Services total & 160 & 186 & 204 & 236 & 238 & 254 \\
& Trade, hotels and restaurants & 65 & 84 & 84 & 95 & 100 & 98 \\
& Other services activities & 94 & 102 & 121 & 140 & 137 & 155 \\
\hline
\end{tabular}


Immigration in Italy between First and Second Republic. From the Reception Policies...

\begin{tabular}{|c|c|c|c|c|c|c|c|}
\hline Territory & & 2005 & 2006 & 2007 & 2008 & 2009 & 2010 \\
\hline \multirow{8}{*}{ North-West } & Total & 271 & 302 & 320 & 372 & 378 & 387 \\
\hline & Agriculture, hunting and fishing & 8 & 10 & 11 & 14 & 15 & 12 \\
\hline & Industry total & 169 & 178 & 188 & 212 & 221 & 226 \\
\hline & $\begin{array}{l}\text { Industry total excluding } \\
\text { construction }\end{array}$ & 98 & 99 & 107 & 115 & 113 & 119 \\
\hline & Constructions & 71 & 78 & 81 & 97 & 108 & 107 \\
\hline & Services total & 94 & 115 & 121 & 146 & 142 & 150 \\
\hline & Trade, hotels and restaurants & 39 & 51 & 45 & 52 & 56 & 56 \\
\hline & Other services activities & 54 & 63 & 76 & 94 & 86 & 93 \\
\hline \multirow{8}{*}{ North-East } & Total & 207 & 232 & 261 & 295 & 294 & 303 \\
\hline & Agriculture, hunting and fishing & 8 & 7 & 6 & 7 & 8 & 10 \\
\hline & Industry total & 134 & 154 & 171 & 199 & 191 & 189 \\
\hline & $\begin{array}{l}\text { Industry total excluding } \\
\text { construction }\end{array}$ & 89 & 94 & 106 & 126 & 124 & 117 \\
\hline & Constructions & 44 & 60 & 65 & 73 & 67 & 72 \\
\hline & Services total & 66 & 71 & 83 & 89 & 95 & 104 \\
\hline & Trade, hotels and restaurants & 26 & 32 & 39 & 43 & 44 & 42 \\
\hline & Other services activities & 40 & 39 & 45 & 47 & 51 & 62 \\
\hline \multirow{8}{*}{ Centre } & Total & 152 & 178 & 197 & 220 & 239 & 265 \\
\hline & Agriculture, hunting and fishing & 10 & 8 & 10 & 11 & 15 & 16 \\
\hline & Industry total & 76 & 97 & 113 & 128 & 135 & 149 \\
\hline & $\begin{array}{l}\text { Industry total excluding } \\
\text { construction }\end{array}$ & 33 & 36 & 39 & 50 & 51 & 53 \\
\hline & Constructions & 43 & 62 & 74 & 78 & 84 & 96 \\
\hline & Services total & 66 & 73 & 74 & 81 & 89 & 100 \\
\hline & Trade, hotels and restaurants & 24 & 33 & 33 & 37 & 40 & 48 \\
\hline & Other services activities & 42 & 40 & 41 & 44 & 49 & 51 \\
\hline \multirow{8}{*}{ South } & Total & 81 & 81 & 92 & 105 & 115 & 132 \\
\hline & Agriculture, hunting and fishing & 15 & 14 & 12 & 14 & 18 & 23 \\
\hline & Industry total & 17 & 24 & 30 & 35 & 39 & 46 \\
\hline & $\begin{array}{l}\text { Industry total excluding } \\
\text { construction }\end{array}$ & 5 & 7 & 11 & 12 & 12 & 14 \\
\hline & Constructions & 12 & 17 & 19 & 23 & 27 & 32 \\
\hline & Services total & 49 & 43 & 50 & 56 & 58 & 63 \\
\hline & Trade, hotels and restaurants & 28 & 26 & 30 & 36 & 36 & 41 \\
\hline & Other services activities & 21 & 18 & 20 & 21 & 22 & 22 \\
\hline
\end{tabular}

Source: ISTAT - Rilevazione Oros (occupazione, retribuzioni, oneri sociali): 2005-2010 
Table 9

Foreigners employed from 15 years old and over surveyed by profession 2011 (data in thousands)

\begin{tabular}{|c|c|c|c|c|}
\hline Territory & Employment & Males & Females & Total \\
\hline \multirow{5}{*}{ Italy } & Qualified Personnel and technicians & 64 & 73 & 137 \\
\hline & Employees in charge of trade and services & 137 & 343 & 480 \\
\hline & Workers and craftsmen & 647 & 92 & 739 \\
\hline & Unqualified personnel & 289 & 385 & 674 \\
\hline & Total & 1.137 & 894 & 2.030 \\
\hline \multirow{5}{*}{ North } & Qualified personnel and technicians & 42 & 51 & 93 \\
\hline & Employees in charge of trade and services & 75 & 205 & 280 \\
\hline & Workers and craftsmen & 452 & 65 & 517 \\
\hline & Unqualified personnel & 151 & 206 & 358 \\
\hline & Total & 720 & 527 & 1.247 \\
\hline \multirow{5}{*}{ North-West } & Qualified personnel and technicians & 25 & 26 & 51 \\
\hline & Employees in charge of trade and services & 48 & 117 & 165 \\
\hline & Workers and craftsmen & 246 & 30 & 276 \\
\hline & Unqualified personnel & 87 & 129 & 217 \\
\hline & Total & 407 & 301 & 709 \\
\hline \multirow{5}{*}{ North-East } & Qualified personnel and technicians & 16 & 25 & 42 \\
\hline & Employees in charge of trade and services & 26 & 88 & 115 \\
\hline & Workers and craftsmen & 206 & 35 & 241 \\
\hline & Unqualified personnel & 64 & 77 & 141 \\
\hline & Total & 313 & 226 & 539 \\
\hline \multirow{5}{*}{ Centre } & Qualified personnel and technicians & 17 & 18 & 35 \\
\hline & Employees in charge of trade and services & 40 & 85 & 126 \\
\hline & Workers and craftsmen & 150 & 21 & 171 \\
\hline & Unqualified personnel & 68 & 117 & 185 \\
\hline & Total & 275 & 242 & 517 \\
\hline \multirow{5}{*}{ South } & Qualified personnel and technicians & 6 & 4 & 10 \\
\hline & Employees in charge of trade and services & 21 & 53 & 74 \\
\hline & Workers and craftsmen & 45 & 6 & 51 \\
\hline & Unqualified personnel & 69 & 61 & 131 \\
\hline & Total & 141 & 124 & 266 \\
\hline
\end{tabular}

Source: ISTAT - Rilevazione Oros (occupazione, retribuzioni, oneri sociali): 2011 
Immigration in Italy between First and Second Republic. From the Reception Policies...

\section{Table 10}

Resident foreigners employed from 15 years old by profession (2017, data in thousands)

\begin{tabular}{|c|c|c|c|c|}
\hline Territory & Employment & Males & Females & Total \\
\hline \multirow{5}{*}{ Italia } & Qualified personnel and technicians & 79 & 94 & 173 \\
\hline & Employees in charge of trade and services & 221 & 507 & 728 \\
\hline & Workers and craftsmen & 612 & 75 & 687 \\
\hline & Unqualified personnel & 432 & 402 & 834 \\
\hline & Total & 1.344 & 1.079 & 2.423 \\
\hline \multirow{5}{*}{ North } & Qualified personnel and technicians & 54 & 62 & 116 \\
\hline & Employees in charge of trade and services & 122 & 287 & 409 \\
\hline & Workers and craftsmen & 410 & 53 & 463 \\
\hline & Unqualified personnel & 216 & 217 & 434 \\
\hline & Total & 802 & 620 & 1.422 \\
\hline \multirow{5}{*}{ North-West } & Qualified personnel and technicians & 34 & 38 & 71 \\
\hline & Employees in charge of trade and services & 84 & 158 & 243 \\
\hline & Workers and craftsmen & 229 & 24 & 253 \\
\hline & Unqualified personnel & 128 & 135 & 263 \\
\hline & Total & 475 & 355 & 830 \\
\hline \multirow{5}{*}{ North-East } & Qualified personnel and technicians & 20 & 25 & 45 \\
\hline & Employees in charge of trade and services & 38 & 129 & 166 \\
\hline & Workers and craftsmen & 181 & 29 & 210 \\
\hline & Unqualified personnel & 88 & 82 & 171 \\
\hline & Total & 327 & 265 & 592 \\
\hline \multirow{5}{*}{ Centre } & Qualified personnel and technicians & 19 & 26 & 46 \\
\hline & Employees in charge of trade and services & 66 & 140 & 206 \\
\hline & Workers and craftsmen & 147 & 17 & 164 \\
\hline & Unqualified personnel & 102 & 120 & 222 \\
\hline & Total & 334 & 303 & 637 \\
\hline \multirow{5}{*}{ South } & Qualified personnel and technicians & 6 & 6 & 12 \\
\hline & Employees in charge of trade and services & 34 & 79 & 113 \\
\hline & Workers and craftsmen & 55 & 5 & 60 \\
\hline & Unqualified personnel & 113 & 65 & 178 \\
\hline & Total & 208 & 156 & 363 \\
\hline
\end{tabular}

Source: ISTAT - Rilevazione Oros (occupazione, retribuzioni, oneri sociali): 2017 
Basically, looking again at the analyses contained in the last Caritas and Migrantes report (RICM 2017-2018), on $1^{\text {st }}$ January 2018 Italy, with 5.144 .440 immigrants regularly residing on their territory $(8,5 \%$ of the total population resident) ranks 5th in Europe and 11th in the world. According to the UNHCR, between $1^{\text {st }}$ January and $31^{\text {st }}$ August 2018, 80\% fewer migrants landed in Italy than in the same period in 2017. The largest foreign communities are Romanian (1.190.091 people, equal to $23,1 \%$ of total immigrants), Albanian (440.465, 8,6\% of the total), and Moroccan (416.531, 8,1\%). Foreign citizens are mainly residing in the North-West of the Peninsula $(33,6 \%)$ and decreasing in the Centre $(25,7 \%)$, in the North-East $(23,8 \%)$, in the South $(12,1 \%)$ and in the Islands $(4,8 \%)$. The regions in which the largest number of foreign citizens are Lombardy (1.153.835 resident foreign citizens, equal to $11,5 \%$ of the total resident population), Lazio $(679.474,11,5 \%)$, EmiliaRomagna (535.974, 12\%), Veneto (487.893, 10\%), and Piedmont (423.506, $9,7 \%)$. The provinces where the largest number of foreign citizens are Rome (556.794, 12,8\%), Milan (459.109, 14,2\%), Turin (220.403, 9,7\%), Brescia $(156.068,12,4 \%)$, and Naples $(131.757,4,3 \%)^{9}$.

\section{From the «emergency» management of migrations to the «Turco-Napolitano» Law}

The new migration «model» found Italy quite unprepared in regards to both reception and integrating migrants ${ }^{10}$. The poor legislative framework for immigration, as well as being outdated ${ }^{11}$, was also «characterized by a fragmentary and incomplete nature» ${ }^{12}$, and focused on the re-

9 Chiara, Frisone, 2016; Chiara, 2011 and 2013; UNCHR (United Nations High Commissioner for Refugees), Report on Political Refugees, 2011; CARITAS and MIGRANTES (RICM), XXIII Immigration Report 2013 - Summary; Id., Presentation of the Immigration Statistical Dossier, Rome 2011; Id., XXVII Immigration Report, 2017-2018A new language for migrations; Pugliese, 2002; Molina, 2011; Sori, 2003; Collinson, 1994; Bevilacqua, De Clementi, Franzina, 2001 and Idd., 2002; Checco, 2000.

${ }_{10}$ Within Southern Europe countries we can scan a sort of «Mediterranean pattern of immigration»: large settlement of foreigners not related to call for industrial labor. Germani, 2001; Campani, 2008, p. 182; Vitiello, 2008. A diverse pattern has been developed on the «South-North» axis in Europe; Sparschuh, 2014.

11 Consolidated Law of Public Security, artt. 150-152, R. D. $18^{\text {th }}$ June 1931, n. 773.

12 Ongoing translations from Italian reported in this paper are an authors' adaptation; Bonini, 1987, p. 105. 
cruitment of people from abroad, and regularization of foreign workforce already active inside the country ${ }^{13}$.

The first Circulars issued by the Ministry of Labor in the 1980s, created a cumbersome procedure; a framework that resulted in the opening of many amnesties for irregular positions. The abuse of foreign labor, in some cases, also led to problems with the home countries, as happened with Tunisians employed in Sicilian fisheries, agriculture or construction sectors ${ }^{14}$.

The Tunisians were often temporary migrants, clandestine, and their presence affected the local work market, and triggered the first reactions of hostility from locals; the Italian government had to deal with Tunisian politicians to solve this issue.

In 1977 the Italian Constitutional Court called for a reorganization of migrations policies that took into account «the need to consecrate in a complete and organic set of rules, practices and guarantees to fullfill fundamental human freedoms, relating to the arrivals of foreigners, and residency permits in Italy» ${ }^{15}$.

Without dwelling too much on the Seventies, it seems to be useful for our analysis to identify a first, specific, feature of Italian immigration policies. This feature will remain the same until the early Eighties: it's the non-organic and mainly administrative nature of the legislation, due to the government's lack of understanding of the irreversible changes taking place not only within the economic and social structure of the country, but also within the global scenario.

We can think about, for example, how the European integration process also affected the mobility patterns ${ }^{16}$ : from the freedom of movement,

13 The Circular n. 51/22/IV, $4^{\text {th }}$ December 1963, is the first administrative act released by the Ministry of Labor («Provisions for the employment of foreign labor in Italy»). Einaudi, 2007, pp. 80-99; Madonia, 1975; Cusumano, 1976; Sbraccia, Saitta, 2003.

${ }^{14}$ Circular of $21^{\text {th }}$ July $1975,7 / 122$ II (to restrict abuse of foreign labor in caregiving field); Circular of $21^{\text {th }}$ May 1979 n. 8026; Circular of $17^{\text {th }}$ December 1979, n. 140/90/79 (new provisions for arrival and employment of non-EU citizens in caregiving area); Einaudi, 2007, p. 108. A large number of amnesties followed up until 1982 (Circular of $2^{\text {nd }}$ March 1982, n. 14194/IR/A) Bontempelli, 2009, p. 118.

${ }^{15}$ Constitutional Court judgement, $20^{\text {th }}$ January 1977, n. 47; Colucci, 2018, p. 13. Italian Constitution provides for protection to foreigners (Costituzione della Repubblica Italiana, art. 10).

16 The European framework on migration issues was linked to the international principles established by the Charter of the United Nations (1945); by the United Nations Universal Declaration of Human Rights (1948), articles 13 (paragraphs 1 and 2) and 14, about the freedom of movement and residence within the borders of each state and the right to leave one's own country, and the right to have asylum; the Geneva Convention relating to 
to a unique framework for the labor market, to the growth of trans-European infrastructure networks, all these elements made easier to European workers to occupy the Italian market, characterized only by scattered provisions about illegal labor (the only provisions about foreign workforce were issued both by the Ministry of Labor and Ministry of Interior) ${ }^{17}$.

During the second half of the Eighties, Italy ratified the multilateral agreement signed on June 1975 (the ILO Convention) ${ }^{18}$ : in 1986 the «Foschi law» was born, the first organic intervention to deal with the «recruitment and treatment of non-EU immigrant workers and against illegal immigration» (1. 943/1986).

The entities most responsible for reception, such as the Regions and the Regional Councils of emigration and immigration, pushed for the development of this apparatus. Trade Unions were also engaged in negotiation with the government about the arrivals management; even EU - who was in the process of eliminating border controls between intra-EU countries after the Schengen Agreement in $1985^{19}$ - dealt with the issue in several work sessions, converging on the special need for cooperation on this matter ${ }^{20}$. The Single European Act, in 1986, developed a relative shift

the status of refugees (1951). These principles were incorporated by the European Convention on Human Rights (1950), validated by subsequent jurisprudence, and explicitly confirmed by the Treaty of Rome (1957) that underlined the will of European countries to guarantee a harmonious development of the economy, also through the free movement of people, established by Title III, Chapter I. From the second post-war period, these principles were related mostly to the economic reconstruction, and therefore also to guarantee the greater ease of placement of the workforce on the global scenario.

${ }_{17}$ For the most, high qualified labor and students (Loreto, 2018). The foreign labor employment was more convenient within the industrial factories, because these workers are not protected by CEE provisions. Sparschuh, 2014, p. 33; Bade, 2000.

18 The Convention n. 143 concerning Migrations in abusive conditions and the promotion of equality of opportunity and Treatment of Migrant Workers (June 1975) was ratified in Italy into law n. 158 of $10^{\text {th }}$ April 1981.

19 Article 7 of the Schengen Convention provided for the obligation for each States to «bring closer the visa policies in the shortest time, in order to avoid the negative consequences that may result from easing controls at common borders on immigration and security», and to adopt the «necessary provisions in order to apply the procedures for issuing visas and admission on their territory, taking into account the need to guarantee the protection of all the territories of the 5 States from illegal immigration and from those activities that could threaten security».Cfr. https://www.camera.it/_bicamerali/schengen/fonti/ACCSCHEN/infdx.htm

20 About European situation, and how Italy dealt with it, see the content of the Bill presented by democratic MPs Foschi et alii, n. 796, $9^{\text {th }}$ November 1983, or the official recap of XIII ${ }^{\circ}$ Labor Commission $-3^{\text {rd }}$ April 1986. 
Immigration in Italy between First and Second Republic. From the Reception Policies...

of competence towards the European Community about addresses the general lines of intervention in the matter of entry, circulation and residence of third-country people.

However, in this years, Italy was not included the Schengen $\operatorname{area}^{21}$ : the lack of specific rules on asylum and protection of personal data (related to the establishment of the first SIS database ${ }^{22}$ ), as well the «geographical restrictions» to the Geneva Convention, made very difficult the full access of the country into the area of free circulation for security reasons.

The «Foschi law» guaranteed full equality for foreign workers, and a brand new amnesty for all irregular workers who arrived before 1986 . Unfortunately, this law showed limited effectiveness both in management of arrivals and enforcement of sanctions for illegal work (foreigners often bypassed the chaotic bureaucracy of residency permits rather opting to adopt simple touristic visas requests) ${ }^{23}$.

The Parliament dealt up the immigration issue «in terms of human and civil rights, and of consistent with international conventions» ${ }^{24}$, by helping integration, also with the aim of dismantle the first social strains and xenophobia among people ${ }^{25}$. This attitude did not find an echo in Italian media, which were spreading a «positive» image of migrants, too often victim of exploitation and crimes connected to marginality they were forced to live ${ }^{26}$.

At the beginning of the Nineties the curtain was raised on the socalled «Second Republic».

Populistic movements were born within the northerner regions - the Northern League and the Venetian League - and began to gather more and more support also in the Southern Italy. They proposed themselves as an al-

21 About the Italian limits related to the Schengen Agreement, Hein, 2010, pp. 40-41.

22 The «Schengen Information System», managed personal info of people illegally entering and then expelled; it represents, together with the first cross-border police activities of the «Trevi Group» (terrorism, radicalism, extremism and international violence) starting since 1975, the first attempts of international cooperation regarding the control of illegal immigration and the fight against crime; Brouwer, 2008.

${ }^{23}$ About the conflicts of this law with the previous Circulars issued, Chiaromonte, 2013, p. 106.

${ }^{24}$ Foschi et alii, Bill n. 796, $9^{\text {th }}$ November 1983.

25 Colucci and Loreto reported the story of the South-African laborer Jerry Masslo, killed in 1989, as the first turning point within Italian migration policies. Colucci, 2018, p. 18; Loreto, 2018, p. 87, Einaudi, 2007, pp. 134-135.

26 About the representation of migrants on media, Sciortino, Colombo, 2004. 
ternative to the traditional parties swept away by a deep ideological and moral crisis, and judicial inquiries ${ }^{27}$. The strongly «ethno-nationalist» perspective about the development process and the related economic policies proposed by the League, were spread through a strong propaganda around some topics, such as the fiscal «secession» of the northern regions; euro-skepticism; the defense of internal security and the forced stop to the immigration.

All this topics turned in a new path, that placed different concepts and problems on the same level, like illegal immigration, security, emergency ${ }^{28}$; this propaganda was earmarked to spread a wide "phobia» among people, also supported by the mounting threat of terrorism ${ }^{29}$ and the first «politicization» of extra-community citizens theme ${ }^{30}$.

This propaganda was being strengthened, from 1989, due to the instability caused by the «Iron curtain» fall: the progressive breakdown of communist regimes led millions of people, within a decade, to move towards west, while the first criminological investigations about the foreigners crime rate were developed ${ }^{31}$.

The need of useful tools for the management of migrants led the Italian government to the law n. 39/1990, which introduced preventive and repressive measures on immigration ${ }^{32}$. This law found its raison d'être - and unfortunately also showed its limits - during the first, dramatic, arrivals by sea from Albania ${ }^{33}$, and the occurrence of many requests of international protection forwarded by migrants fleeing ongoing conflicts in Rwanda, Somalia, Croatia (1991-1995) and, above all, Bosnia and Herzegovina (1992-1995).

27 On this historical change in Italy, Colarizi, Gervasoni, 2012.

28 About the raise of the Northern League, Colarizi, Gervasoni, 2012; Passalacqua, 2010; Dematteo, 2001; Tranfaglia, 2014, Barcella, 2018.

${ }_{29}$ Terrorist attacks increased, such as Achille Lauro boat hijacking or Fiumicino shooting against Israeli $\mathrm{El} \mathrm{Al}$ and the American TWA airlines, on $27^{\text {th }}$ December 1985; Bocca, 1988, Cava, 2011.

30 Between 1989 and 1997 media transformed foreigners in «extra-community» citizens, in the specific sense of people «left out» the national community; Sciortino, Colombo, 2004; Ginsborg, 1998, p. 121; Der Wal, 1991.

31 Raffaele, 2019.

32 The «Martelli Law» provides for the first time in Italy the rejection procedure related to migrants socially dangerous, and introduces the quota system for managing inflows. Every year the government would have to prepare a decree for planning arrivals. Bontempelli, 2009, p. 122; Chiaromonte, 2013, p. 111; Colucci, 2018, pp. 18-20

33 On March 1991 landed on Italian shores almost 25.700 Albanian. On August, more than 12.000; Mai, 2002, pp. 77-94; Palomba, Righi, 1993. 
Immigration in Italy between First and Second Republic. From the Reception Policies...

A large number of asylum seekers moved westward, arriving for the first effects of perestroika or the Middle East crisis. Meantime, the international agreements about the resettlement of many refugees «under UNHCR mandate» were over, and this led Italy to went over the comfortable situation of «transit country»: now, with the Martelli law, refugees could convert their requests and be hosted inside the country ${ }^{34}$.

In the same year, Italian acceptance within the Schengen area (1990) ${ }^{35}$ made it clear that the country needed tools to control the external borders, and to harmonize the national immigration and asylum policies to the European framework, erasing the «geographical restriction» to the Geneva Convention, and according to the outlined international treaties and guidelines ${ }^{36}$, for the future establishment of a Common European Asylum System (CEAS) ${ }^{37}$.

The exceptional measures about immigrations went beyond the «Martelli law» (n. 39/90).

Between 1993 and 1996 the government largely issued emergency decrees $^{38}$, producing an «ordinary daily management» made up of «continuous emergencies (facilities, labor, social services, racism, waves of arrivals, controversy over expulsions)» ${ }^{39}$, and forgetting to work on a flow scheduling commensurate with the real needs of the labor market ${ }^{40}$.

New elections, in 1996, brought a center-left coalition to government for the first time after World War II. The Northern League - which had gained a solid consensus in the north-eastern regions of the country - and

${ }^{34}$ About resettlement and statistical data, UNHCR Resettlement Handbook, 2001 and Hein, 2016, p. 42.

35 In 1990 Italy signed the Schengen Agreement, but delayed its application until 1997 also due to immigration increase.

${ }^{36}$ On $15^{\text {th }}$ June 1990 also Italy signed the Dublin Convention, ratified by law on $23^{\text {th }}$ December 1992, n. 523. In 1992 Italy joined the Maastricht Treaty, which includes the control of migration flows within the so-called third pillar, adopted for cooperation in the sphere of justice and internal affairs. Under the Amsterdam Treaty, which came into effect in May 1999, immigration has become a sector of EU supranational competence, thus laying the foundations for a common European asylum, https://www.easo.europa.eu/sites/default/files/easo-introduction-to-ceas-ja_it.pdf.

37 Tonini, 2010, p. 289.

38 Conso decree, $14^{\text {th }}$ June 1993, n. 187, converted into law 12 $2^{\text {th }}$ Agust 1993, n. 296; Dini decrees, $18^{\text {th }}$ November 1995 , n. 489 , not converted into laws.

39 Einaudi, 2007, p. 155.

40 The government did not plan any quota for inflows, going on with the old prevision of law 943/86. Ministery of Foreign Affairs Decree, $17^{\text {th }}$ November 1990. Einaudi, 2007, p. 171 and Bontempelli, 2009, p. 123. 
Silvio Berlusconi and his «Freedom Pole» coalition, led within the Parliament a strong challenge to the immigration phenomenon. The public opinion showed a certain support to this action, especially after the unedifying results of the rescue operations to the Albanians landed in Puglia; people were also impressed by a presumed crimes increase announced by the press ${ }^{41}$.

The EU directives dedicated to the protection of «non-EU» refugees rights, as well as to the arrivals control, had furthermore an important footprint on Italian legislative provisions of the late Nineties. In a nutshell, the laws framework started to put attention to «quota system», «permanent control» and «integration policies» ${ }^{42}$. It should also be remembered that since 1999 the European Union has committed for finding a common policy for its members about asylum seekers, how to give the status of beneficiary of international protection and its content, as well as for the recognition and revocation procedures of the refugee status $^{43}$.

Meantime, new refugees came from Turkey - Kurds get out from the Northern Iraq ${ }^{44}$ - and EU partners were concerned about Italy's ability to handle new «emergencies»; these worries were expressed from Germany and France, whom were able to slow down the full integration of Italy within the European free circulation area ${ }^{45}$.

The government launched the law n. 40/1998 called «Turco-Napolitano», the first organic and non-emergency provision concerning immigration in Italy. This law followed the priority interest of re-build a strong international reputation, also played on the ability to quickly provide a credible migration policy, geared towards «greater strictness in controlling external borders» and «able to meet the Schengen requirements».

This new law reintroduced the principle of scheduling flows to regulate incoming; «citizenship paths» for helping integration and immigrant

$41 \ll[\ldots]$ in particolare dello sfruttamento della prostituzione, anche infantile, del traffico degli stupefacenti, e dei reati contro il patrimonio, la connessione tra criminalità organizzata albanese e italiana», Einaudi, 2007, p. 211.

42 Pugliese, 2002, p. 79.

43 See the Guideline 2001/55/CE; Rules of procedures (CE) n. 2725/2000; Guideline 2001/55/CE; Rules of Procedures (CE) n. 343/2003; Rules of Procedures (CE) n. 1560/2003; Guideline 2003/9/CE; Guideline 2004/83/CE; Guideline 2005/85/CE.

${ }^{44}$ La Repubblica, $3^{\text {rd }}$ Novembre 1997, Curdi in fuga da Saddam e dalle guerre fratricide.

45 Paoli, 2018; Fridegotto, 1992. 
rights; improved the repressive tools and the refoulement of illegal immigrants, and reinforced the fight against organized crime. In line with other European countries, the law 40/98 introduced the CPT (temporary reception centers), used to hold a refugee for rescue and/or identify him, or to reject him at the border, or expel him by police intervention.

The law 40/98 converged, a few months after its approval, into the decree n. 286/1998, called the Consolidated Law on Immigration ${ }^{46}$. The «Turco-Napolitano» law, and the subsequent Consolidate Law, still left without references the much more complex issue of asylum ${ }^{47}$, too long confused with the international protection guaranteed to the refugee: the recognition of refugee status ${ }^{48}$, in fact, remained those generally provided by the «Martelli Law», art. 1. These article was a re-proposal to the $G e$ neva Convention ${ }^{49}$, except for the abolition of the "geographical restriction»; the matter of asylum is still lacking an organic law that establishes the conditions of its exercise.

More difficult was the application of the discussed principle of nonrefoulement of those seeking protection for humanitarian reasons, a principle sanctioned by international laws ${ }^{50}$; non-refoulement didn't match with the hard policy undertaken by the government, who to prevent the landing on the Italian coasts of boats with migrants didn't hesitate imple-

46 Decree of the President of the Republic, $31^{\text {th }}$ August 1999, n. 394, «Rules for the implementation of the Consolidated Act of Immigration and rules on the status of foreigners, according to art. 1, paragraph 6, of the legislative decree 25 July 1998, n. 286».

47 Asylum is guaranteed in Italy by international laws and by article 10, third paragraph, of the Italian Constitution, which provides that the foreigner who is prevented in his country from actually exercising the guaranteed democratic freedoms, has the right to asylum in the territory of the Republic.

48 The refugee is a foreign citizen who is recognized as having suffered persecution for reasons of race, religion, nationality, belonging to a particular social group or political opinion in the country of which he is a citizen and which cannot, for fear, make use of protection of that country. He is protected by Geneva Convention of $28^{\text {th }}$ July 1951 (ratified in Italy with law $24^{\text {th }}$ July 1954, n. 722), and by the Dublin Convention of $15^{\text {th }}$ June 1990 (ratified in Italy with law $23^{\text {th }}$ December 1992, n. 523).

49 In 1999 applications for asylum reached around 33.000, following the dramatic exodus of thousands of Kosovars and Albanians fleeing ethnic cleansing perpetrated by Serbian President Milosevic.

50 Those who benefit humanitarian protection are not recognized as refugees, because they are not victims of individual persecution in their country, but still need protection and/ or assistance because they are particularly vulnerable from a medical, psychological or social point of view or because if they were repatriated they could suffer violence or abuse. European standards define this type «subsidiary» protection. 
menting a «naval block» ${ }^{51}$. This choice was strongly denied by international organizations ${ }^{52}$ and by the other parties of the majority coalition, but found Northern League consensus, such as in several Italian municipalities and regions no longer willing to accept the refugees ${ }^{53}$.

Italian media frequently broadcast news with foreigners and clandestine, and assumed alerted tones after the Twin Towers attack on 11th September 2001, and the subsequent terrorist attacks claimed by Islamic terrorism ${ }^{54}$. EU, with the Directive 2001/55/EC, established minimum standards for granting temporary protection in the event of a mass influx of displaced persons from third countries, in order to lighten the burden of the host countries (due to the large number of displaced people arriving from the former Jugoslavia) ${ }^{55}$.

\section{From the «Bossi-Fini Law» to the «Security and Immigration Decree law»}

At the beginning of the $21^{\text {st }}$ century, immigration in Italy was not perceived as a structural dimension, but as a very problematic variable.

These migration flows were settled inside the country unevenly, saturating the hosting capacity of regions, and generating reactions of hostility ${ }^{56}$.

51 On $28^{\text {th }}$ March 1997 an Italian military patroller hit in high sea the boat Kater I Rades. More than 100 people deceased, also women and children. Il Manifesto, Kater I Rades, una memoria che brucia ancora, 1997-2017. Un misfatto made in Italy, 28 marzo 2017.

52 ONU criticized Italy for damaging the human rights of people on board, and asked for the removal of the naval blockade. Prime Minister Prodi replied it was «effective patrolling» in high sea. Corriere della Sera, L'ONU all'Italia: via il blocco navale, 28 marzo 1997.

53 Einaudi, 2007, p. 294.

54 Only for Europe: Beslan School Siege, 2004 - 385 deceased; Madrid, 2004 - 191 deceased; 2005 London - 56 deceased.

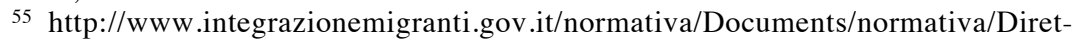
tive\%20Recepite/Direttiva\%202001_55_CE.pdf

56 A survey carried out by Fondazione Nord Est revealed how the population considered immigration a «danger to their own culture and identity» $(23,9 \%)$, «a threat to job opportunities» $(29,2 \%)$ and «to public order and security» $(39,7 \%)$. In terms of territorial distribution and in relation to job opportunities throughought the peninsula, in 2003 the majority of foreign citizens was in North-Western Italy. Dossier statistico Immigrazione Caritas-Migrantes 2003, XII ${ }^{\circ}$ Rapporto «Italia, paese di immigrazione», Edizioni Nuova Anterem, 2003. 
Immigration in Italy between First and Second Republic. From the Reception Policies...

In this changed socio-economic and political context, the center-right coalition led by Silvio Berlusconi triumphed in the 2001 elections, making immigration one of the pillars of his electoral campaign, and subsequent political action. Compared to what was proposed by the Northern League - member of the new coalition - the government reached a «moderate» solution. This was largely due to the pressures exercised by the catholic political world, the center parties, the whole universe of small and medium companies relying on the essential contribution of immigrant labor, as well as the sector of assistance and care for the families (caregivers, etc.).

The launch of law n. 89/2002, known as «Bossi-Fini Law», affected both the Turco-Napolitano Law and the 1998 Consolidated Act by strengthening the measures against illegal immigrants and traffickers.

The law appeared quite controversial on two main issues, the first one of which concerned to asylum seekers. Specifically, was born the «Protection system for asylum seekers and refugees» (SPRAR), defined as the «pivot of the reception system both for adults and for all foreign unaccompanied minors», but, in reality, the physical place were asylum seekers were blocked for a long time while they were waiting for the validation of their status ${ }^{57}$.

Another controversial point referred to the long-standing issue of nonrefoulement at sea.

The refoulements made in extraterritorial waters increased due to bilateral agreements with countries such as Egypt and Libya, that committed their national polices to cooperate with Italy to prevent illegal immigration $^{58}$. This agreement required a subsequent «internment» of migrants

57 The Protection System for Asylum and Refuge Seekers, the so-called «second reception», is established by the Department for Civil Liberties and Immigration of the Ministry of Interior and operated by Anci (the National Association of Italian Municipalities). Applicants who have filed a request for asylum and have no means of subsistence (determined by the welfare check annual amount) are brought into the system of secondary level reception centres. Besides food and shelter, SPRAR must provide services such as linguistic and cultural mediation, Italian language courses, vocational training and guidance and legal assistance so as to facilitate integration. Accommodation is granted for six months, which can be extended for a further six months and is in any case guaranteed until the decision of the Territorial Commission or, in case of appeal, until the outcome of the suspension request and/or the definition of the first degree proceeding. Marchetti, 2014.

58 Significant quotas of migrants from Sub-Saharian Africa converged in Libya. Thanks to the Treaty on Friendship, Partnership and Cooperation between Italy and Libya agreed with Colonel Muammar Gaddafi, illegal migrants in transit through Libya could 
on arrival, before being repatriated to their countries. This procedure was far from meeting the international protection granted to refugees by the Charter of Fundamental Rights of the European Union (Italy was condemned by the ECHR) and above all, by the Geneva Convention itself (Libya did not subscribe the Convention).

The first phase of implementation of the common European Asylum System, were approved on $18^{\text {th }}$ February 2003, with the Regulation n. 343 called Dublin II, which replaced the Dublin Convention of 1990: an element of novelty was represented by the possibility for a member state to take charge of asylum applications regardless of the consent of the interested person ${ }^{59}$.

From the passing of the Bossi-Fini Law (2002) until the fall of the last Berlusconi government (2011), foreign population grew from 1.334.889 to 4.027.627. The largest communities on the territory, namely Romanian, Albanian, Moroccan, Chinese, Ukrainian were also the ones who had settled for the longest period of time in Italy ${ }^{60}$.

In 2008 the Minister of the Interior Roberto Maroni (Northern League) introduced the so-called «Security package» ${ }^{61}$ - consisting of one decree law, two bills, three legislative decrees - that dealt with immigration as part of measures aimed at public security. The decrees introduced the crime of illegal entry and staying in Italy, as well as sanctions for the crime of abetting illegal immigration; charges and duties for foreigners seeking a permit of residence, including test of Italian language ${ }^{62}$.

be repatriate to their countries of origin, with repatriation expenses covered by Italy. Furthermore, Berlusconi government guaranteed assistance and training to Libyan police personnel, ended the EU embargo towards the country, and implemented the construction of transit camps to improve the condition of clandestine migrants facing expulsion; a solution criticized by humanitarian organisations for not meeting basic human rights. Einaudi, 2007, p. 331.

59 Already in 1999 the European Council in Tampere, agreed to work on the establishment of a common European asylum system, based on the application of the Geneva Convention in all its components, maintaining the non-refoulement principle. See http://www. europarl.europa.eu/summits/tam_it.htm

${ }^{60}$ Colombo, Sciortino, 2008, p. 8.

61 Interior Minister Roberto Maroni at the launch of 2008 Italian security package: http://www1.interno.gov.it/mininterno/export/sites/default/it/sezioni/sala_stampa/speciali/ Pacchetto_sicurezza/index_2.html.

${ }^{62}$ Law decree n.92, $23^{\text {th }}$ May 2008, on urgent measures on public security matters, passed into law n. 125 on $24^{\text {th }}$ July 2008 ; law n. 94 , $15^{\text {th }}$ July 2009 , carrying regulations on public security matters; law n. $85,30^{\text {th }}$ June 2009 , which ratified the adhesion of the Italian 
Immigration in Italy between First and Second Republic. From the Reception Policies...

Data processed between 1997 and 2014 (with the exception of a peak of 50.000 landings in 1999 due to the war in Kosovo) showed average values contained between 20 and 25 thousand units ${ }^{63}$, with a further decline in the years 2009 and 2010 (with a minimum of 5000 units), probably due to «Security package» effects: quite far from constituting an «invasion», as politicians had feared, but that fed equally widespread discriminatory behaviors and racism ${ }^{64}$.

The growth of a xenophobic feeling, moreover, can usefully be referred to a side effect of the «immigration/crimes» binomial. This combination was completely disconnected from the reality of the data recorded between 2001 and 2008; the number of complaints against immigrants was lower than the immigrants increase, including irregular immigrants and other categories of non-resident foreigners. About the crimes, most of the complaints fell into the area of «common crimes or soft crimes» ${ }^{65}$, confirming that the feeling of a worsening of the safety level was not due to the increase in the foreign population.

More worrying, on the other hand, were the surveys relating to the emigration rates of highly qualified Italian workers - whom according to the 2013 ISTAT data, reached 82.000 units, the highest value of the 2000s. Affected by a labor market crisis, graduates between 20 and 45 years of age preferred destinations such as America, Northern Europe or Oceania: a bigger brain drain, often definitive, than the other four major European countries ${ }^{66}$.

In 2011 arrivals by boat increased due to the Arab Springs, the last turning point to be discussed. The revolutionary cycle, however, produced a general instability increase of the North African area, triggering an un-

Republic to the Prüm Treaty; law decrees n. 159, $3^{\text {rd }}$ October 2008, on the free circulation of EU citizens (later dismissed) and n. 160 on the recognition of refugee status and family reunification.

63 Papavero, 2015.

64 Dossier statistico Immigrazione Caritas-Migrantes 2011, XXI ${ }^{\circ}$ Rapporto «Oltre la crisi, insieme», Ed. Idos, 2011.

65 These included drug trafficking, exploitation of prostitution, extortion, harassment, thefts, mugging, aggressions, as well as crimes related to the violation of the law on immigration (irregularities, escapes, false generalities, resisting, insulting a public officer, illegal occupation of public spaces, etc). Bondi, 2010, also in CNEL, Dossier Statistico immigrazione Caritas/Migrantes. Elaborazione su dati ISTAT e Ministero dell'Interno Dipartimento Pubblica Sicurezza.

${ }^{66}$ Chiara, Frisone, 2016, p. 64; Montanari, 1993. 
controllable domino effect on the articulation and the quantity of migratory flows that crossed the Mediterranean ${ }^{67}$.

The crisis experienced by countries such as Tunisia and Libya (where in the meantime Gaddafi had been deposed by a civil war) determined the interruption of all the agreements previously taken regarding the refoulement and repatriations, and the Italian government, suddenly invested by new waves of arrivals, declared a state of national emergency, also on the basis of the tragic events that took place offshore and on the island of Lampedusa $^{68}$.

From 2012 to 2016, asylum applications and refugees hosted increased from 16.844 to $188.084^{69}$; in the same year, exactly on December $31^{\text {th }}$, a new extraordinary measure was launched by the new government, which insisted on the now well-established binomial «safety/immigration». A Circular was issued by the Interior Minister Minniti, which operated with immediate effect on the expulsions of irregular immigrants, considered «no longer just a problem of public order, but an issue about the stability of the homeland democratic fabric» ${ }^{70}$.

The legislative decrees of $17^{\text {th }}$ and $20^{\text {th }}$ February $2017^{71}$, launched by Minister Minniti, dealt with various issues explicitly linked to migration, calling for «control and regulation of social categories considered dangerous or, at least, threatening, for a certain type of order ${ }^{72}$. The decrees regulated the local authorities in charge of «reception» services that were part of the SPRAR system. It was reserved now only for holders of inter-

67 Bontempelli, 2016.

${ }^{68}$ On $^{\text {th }}$ April 2011 a boat carrying 330 people on board sank near Lampedusa. Italian patrol boats managed to rescue 50, while the remaining migrants, including many women and children, went missing. La Repubblica, Lampedusa, tragedia nella notte. Barcone si inabissa, 250 dispersi, $6^{\text {th }}$ April 2011.

69 Rapporto sulla protezione internazionale in Italia 2017, a cura di Anci, Caritas Italiana, Cittalia, Fondazione Migrantes, with UNCHR, october 2017 Servizio Centrale dello Sprar, in collaborazione con UNHCR - Sintesi, ottobre 2017.

70 «It is not a matter of right-wing policies implemented by a left-wing government, rather the awareness that the path to reception and inclusion of migrants has to be regulated by effective policies of rejection of irregular migrants: La Repubblica, Migranti irregolari, riaprono i Cie: «Raddoppieremo le espulsioni», 31 dicembre 2016.

71 «Disposizioni urgenti per l'accelerazione dei procedimenti in materia di protezione internazionale, nonché per il contrasto dell'immigrazione illegale» e «Disposizioni urgenti in materia di sicurezza delle città» converted into law n. 46 and 48, 13 ${ }^{\text {th }}$ April 2017; Gargiulo, 2018, pp. 151-173.

72 Ivi, p. 157. 
Immigration in Italy between First and Second Republic. From the Reception Policies...

national protection and unaccompanied minors, thus excluding the rest of asylum seekers.

On October $4^{\text {th }}, 2018$, the Norther League and Five Stars government issued the «Security Decree» ${ }^{73}$, which once again places a close link between immigration, public safety, asylum and international protection. The decree n. 113 provides measures to fight against illegal immigration, allowing the implementation of expulsion measures; furthermore, the decree introduces special permits for international protection. Under this profile has been highlighted by jurists the most obvious unconstitutionality feature, followed by various legal actions by the regions and international recalls ${ }^{74}$.

The Minister of Interior Matteo Salvini, leader of the Northern League party, has focused on the migrant issue since the beginning of his election campaign, and had now intensified his actions to fight irregular immigration with the Circular 14100/141 (8) of $15^{\text {th }}$ April 2019. This act substantially established the unavailability of Italian ports to any docking of nonItalian boats (such as the NGOs boats) engaged in rescue operations at sea: this action has been considered by the Minister «due, as well as legitimate and lawful».

The «closed ports» strategy triggered even the reaction of the United Nations, which observed that these directives were nothing more than «another attempt to criminalize the search and rescue operations of civil organizations», as well as a violation of the non-refoulement convention, because Libya, for example, is not a «place of safety» where migrants could be sent back, and that, overall, would have ended up intensifying the climate of hostility and xenophobia towards migrants.

73 Urgent regulations on international protection and immigration, public security, role of the Minister of Interior in the matter, and the organisation and functioning of the National Agency for the Administration and Destination of Confiscated Assets.

74 In early January 2019, Tuscany, Umbria and Emilia-Romagna were among the regions that appealed against the decree. The region of Piedmont also identified the «juridical conditions» to refer to Constitutional Court. «According to the governors, since it prevents visas from being renewed for humanitarian reasons the decree law would have serious consequences on the management of health and care services, which are the responsibility of Regions». Sardinia, Calabria, Basilicata and Lazio seem to have the same intentions. Corriere della Sera, Decreto sicurezza incostituzionale: partono $i$ ricorsi delle Regioni, $7^{\text {th }}$ January 2019. In the meantime, the UN asked Italy to withdraw the governmental directives regarding rescue at high sea and stop the process for approval of the «Security Decree bis» immediately, for it violates human rights. La Repubblica, La lettera dell'ONU al governo italiano: «Il decreto sicurezza bis viola i diritti umani», 18 May 2019. 
According to data provided by the Ministry of the Interior, in the first 5 months of 2019 we record a significant drop in arrivals (approximately 1.878 units) compared to 2017 , which in the same period registered 61.201 landings; as well as the decline in asylum requests, which between 2016 and 2018 went from 123.600 to $53.596^{75}$.

\section{Conclusions}

The statistical data show the extraordinary progression of immigrants arriving in Italy from the 1980s onwards, in conjunction with the more general international economic situation.

We used the historical data series developed by the National Institute of Statistics and the daily Statistical Dashboard of the Ministry of the Interior, leaving aside, for the moment, the changing in the different range of national and global push and pull factors ${ }^{76}$.

The authors' will was to highlight the simultaneous developing of legislation that on alternate way has supported the policies of reception and regulation of migratory flows, and in more recent times has undertaken an emergency profile, reconnecting the provisions of law on migrations to those on public order and security.

It is possible, by general lines, to identify different connected phases related to the structuring of the arrivals, and to the migration policies made by governments.

The first phase (until 1989), is obviously strongly influenced by international contingencies, or rather by the effects of the Cold War on European migration, and the political decisions connected to them. Europe faces the first flow of people who moved from East to West due to political reasons, although often directed outside the continent.

In this framework, it should be pointed out that the impact caused by the collapse of the Wall and the destabilization of the former communist and Balkan area, produced substantial effects in Italy since 2001, when the foreign presence has increased from about one million people in 2001 to around 4 million in 2011.

75 Data from Ministry of Interior, Daily Statistical Dashboard 1990 -2018, http://www. libertaciviliimmigrazione.dlci.interno.gov.it/it/documentazione/statistica/i-numeri-dellasilo

${ }^{76}$ Ravenstein, 1885; Lee, 1966, Mayda, 2007. 
Immigration in Italy between First and Second Republic. From the Reception Policies...

Until 1989 Italy remained a transit country, as confirmed also by the data relating to asylum applications managed by the $\mathrm{UNCHR}^{77}$; due to geographical proximity the country has had to manage more or less considerable amounts of asylum seekers (of European origin), who were temporarily welcomed and then redirected to other destinations.

The Italian position within the continental chessboard responded to international political logic, i.e. the precise policy of the countries of the Western bloc to ensure the opponents of the regime the possibility of having «escape routes», but with any guarantees in terms of long-term stay solutions $^{78}$.

The fall of the «Iron curtain» and the progressive European economic integration, has produced a greater liberalization of internal movements and the need to have shared rules regarding the entry into the EU space of citizens from third countries. So Italy canceled the «geographical restrictions», without, however, for this being equipped with appropriate regulatory instruments to ensure the recognition of the right to asylum, which remains the most evident vulnus to the constitutional principle relating to the foreigners' right to stay within Italy.

It is clear, in fact, how much the lawmaker continues to misunderstand, by one hand, the concept of immigration (the entry and residence of migrants), that can be related to a general assessments of opportunity by government (in relation to the performance of the labor market, the demographic composition of the population, and the social policies), and the asylum or the international protection, not connected to any planning or limitation.

The Nineties opened up a new political phase (second phase) in and out of the country, marked, in Italy, among other things, by the crisis of traditional political parties. At the international level, the creation of the European economic and monetary Union in Maastricht opened (in terms of free circulation and security) a new era of cooperation, and also constraints, with respect to the protection of external borders and the common management of asylum policies.

77 At the end of 1989 there were about 11,500 refugees in Italy, of which fewer than 5,000 of European origin, while in the period 1945-1989 there were about 220,000 refugees resettled through Italy to other destinations.

${ }_{78}$ Hein spoke about the «voting by feet» praxis for communist refugees; Hein, 2010, p. 35 . 
The recognition of fundamental rights remained for a long time secondary - when not neglected - as confirmed by the long process to reform Italian citizenship law, for example, which would facilitate the full integration of all those children born on Italian territory but still not legally considered Italian citizens ${ }^{79}$.

Compared to the 2000 s, the analysis of Italian migration policies made it possible to verify the mismatch between the constant use of extraordinary regulatory provisions on immigration, and the existence of an «emergency» of migrants, as governments in charge claim.

A substantial part of arrivals is still represented by voluntary «economic migrants»; after the 2000s, the arrivals management has given way to a «disciplinary» approach, that is aimed to restrict the issuance of residence permits to economic migrants, and more generally to make the arrival and residence in Italy less and less easy for a large number of migrants who do not have a valid permit, but who are potentially entitled to the recognition of different forms of international protection by ethnicity or place of origin.

However, the political change that took place in Italy with the transition to the Second Republic - but it can be said that a similar trend can also be found in Europe in the same years ${ }^{80}$ - produced the growth and the affirmation of a strongly xenophobic populism, which has politicized the issue of immigration to provide a simplified point of view for the socio-economic crisis of the country. This populism propose the progressive strengthening of the identity concept - in opposition to the foreign presence - and of distrust towards national and European élites, with respect to the restrictions required in the political and economic area.

A populism practiced for example by the League, which in order to obtain greater support throughout the national territory, changed its first regionalist approach, identifying in the foreigner the new «enemy», and presenting itself as a defender of the traditional values of the family and religion; asking for security as expression of sovereignty of the executive power ${ }^{81}$, and building a misrepresented social construction of the migratory phenomenon.

${ }^{79}$ However, it is necessary to note that in public law it is consolidated the interpretation of citizenship no longer as a «privileged status» that guarantees access to civil, social and political rights, as these can be extended to men and women as such.

${ }^{80}$ On the raise of populism in Europe, Mény, Surel, 2001.

81 Also about populism, Revelli, 2017. 
Immigration in Italy between First and Second Republic. From the Reception Policies...

Although the statistical data on irregular entries in Italy are still inaccurate, and referring almost exclusively to the number of boat people that reach the country ${ }^{82}$, it appears clear how much the volumes remain until today not substantial, but within the public opinion the perception of the phenomenon shows an high level of concern.

It is necessary to underline the mismatching between the number of arrivals by sea (which has been declining since 2017) and the unjustified matching of security/immigration proposed by the M5S/League governments, enforced with the latest «Security Decrees».

More than the application of strict border control and sea refoulement, was more effective the partial shift of the North-African coasts control to the Libyan police from 2017, due to the agreements of Italian Minister of Interior with Al Sarraj government (even if substantial humanitarian limits).

The «emergency» laws didn't produce appreciable results in terms of deterrence of illegal immigration, which is firmly attached to criminal networks, economic interests, geopolitical instability and individual motivations, which go beyond the simple control capacities imposed by the national state, and whose trend is not predictable since the migratory pressure from the countries of origin now appears less and less conditioned by the European policies and by the reception and/or refusal measures adopted.

In the same way, the tug-of-war triggered by the Italian government with European partners does not seem to achieve results in terms of political action.

It has been pointed out how the Mediterranean Sea area - the southern border of Europe- represents, today, a «strongly governmentalized» space, that is an area of overlap and intersection of competences and jurisdictions in the field of interception and rescue of boats ${ }^{83}$.

82 Moreover, it is also clear that the «landings» on the Italian coasts are not the only way of illegal access to the country, even if it must also refer to illegal entry at the borders; people who stay beyond the expiry of entry visas; the condition of irregularity caused by the loss of documents, and to a wide range of cases that would have to take into account to balance the quotes of illegal presences inside the country, not exactly quantifiable. In any case, according to the Ministry of the Interior from 181 thousand landings in 2016, it has gone to 119.369 in $2017,23.370$ in 2018, and 10.960 in 2019.

83 Tonini, p. 296. 
Since the 2013 tragedy near the Island of Lampedusa, up to the peak of arrivals reached in 2016 with over 180 thousand arrivals, the flow of migrants to Europe across the sea has highlighted the shortcomings of the Dublin III Regulation (2013/604/Ce), which establishes which member state should be responsible for processing the requests for international protection. This provision leaves countries like Italy and Greece alone in managing the major migratory crisis of recent years.

Although the European Parliament was ready to review the Dublin system according to a principle of responsibility and solidarity among the member states, in June 2018 European Council rejected the proposal of the Parliament for a new Regulation of this matter, due to the pressures of the «Visegrad countries» as well Italy, who opposed against any binding mechanism for the redistribution of migrants who are entitled to political asylum.

But the data relating to the most recent demographic trends confirm a progressive aging of the Italian population, an already consolidated lowering of birth rates and a constant number of population leaving the country, particularly from the South regions and the Islands. Here the growth rates become structurally negative, thus determining a «necessary» immigration demand, aimed at compensating for the need for labor and low fertility levels: in the next future the immigration legislation have to take into account also these elements.

\section{Sources}

Dossier statistico Immigrazione Caritas-Migrantes 2003, XII ${ }^{\circ}$ Rapporto «Italia, paese di immigrazione», Edizioni Nuova Anterem, 2003.

UNCHR (Alto Commissariato delle Nazioni Unite per i Rifugiati), Rapporto annuale 2011; https://www.unhcr.it/wp-content/uploads/2016/01/2011_Rapporto_Annuale.pdf

Dossier statistico Immigrazione Caritas-Migrantes 2011, XXI Rapporto «Oltre la crisi, insieme», Edizioni Idos, 2011.

XXIII ${ }^{\circ}$ Rapporto immigrazione Caritas e Migrantes 2013, «Tra crisi e diritti umani»-Sintesi.

XXVII ${ }^{\circ}$ Rapporto Immigrazione Caritas e Migrantes 2017-2018, «Un nuovo linguaggio per le migrazioni»-Sintesi.

Quaderno Statistico dal 1990 al 2018, Dipartimento per le libertà civili e per l'immigrazione del Ministero dell'Interno.

Rapporto sulla protezione internazionale in Italia 2017, a cura di Anci, Caritas Italiana, Cittalia, Fondazione Migrantes, Servizio Centrale dello Sprar, in collaborazione con UNHCR - Sintesi, ottobre 2017. 
Immigration in Italy between First and Second Republic. From the Reception Policies...

CNEL, Dossier Statistico immigrazione Caritas/Migrantes. Elaborazione su dati ISTAT e Ministero dell'Interno - Dipartimento Pubblica Sicurezza;

PAPAVERO G., Sbarchi, richiedenti asilo e presenze irregolari, Fact sheet ISMU, febbraio 2015, elaborato su dati del Ministero dell'Interno.

\section{Online newspaper}

il Manifesto, Kater I Rades, una memoria che brucia ancora, 1997-2017. Un misfatto made in Italy, 28 marzo 2017

Corriere della Sera, L'ONU all'Italia: via il blocco navale, 28 marzo 1997

La Repubblica, Curdi in fuga da Saddam e dalle guerre fraticide, 3 novembre 1997

La Repubblica, Lampedusa, tragedia nella notte. Barcone si inabissa, 250 dispersi, 6 aprile 2011

La Repubblica, Migranti irregolari, riaprono i Cie: "Raddoppieremo le espulsioni», 31 dicembre 2016

Corriere della Sera, Decreto sicurezza incostituzionale: partono i ricorsi delle Regioni, 7 gennaio 2019

La Repubblica, La lettera dell'ONU al governo italiano: «Il decreto sicurezza bis viola i diritti umani», 18 maggio 2019

\section{Web}

http://www1.interno.gov.it/mininterno/export/sites/default/it/sezioni/sala_stampa/ speciali/Pacchetto_sicurezza/index_2.html

http://www.libertaciviliimmigrazione.dlci.interno.gov.it/it/documentazione/ statistica/i-numeri-dellasilo

https://www.unhcr.it/wp-content/uploads/2016/01/2011_Rapporto_Annuale.pdf

www.larepubblica.it

wWw.ilmanifesto.it

www .corrieredellasera.it

http://www.ismu.org/wp-content/uploads/2015/05/Sbarchi-richiedenti-asilo.pdf

http://www .camera.it/cartellecomuni/leg14/RapportoAttivitaCommissioni/ testi/01/01_cap09_sch06.htm

https://www.camera.it/_bicamerali/schengen/fonti/ACCSCHEN/infdx.htm

https://www.easo.europa.eu/sites/default/files/easo-introduction-to-ceas-ja_it.pdf. http://www .europarl.europa.eu/summits/tam_it.htm 


\section{Bibliography}

BADE K.J., L'Europa in movimento. Le migrazioni dal Settecento a oggi, Laterza, Roma-Bari 2000.

BANTI A.M., «Gli imprenditori meridionali: razionalità e contesto», in Meridiana, 6, 1989, pp. 63-89.

BARCELla P., «Percorsi leghisti. Dall'antimeridionalismo alla xenofobia», in $\mathrm{Me}$ ridiana, 91, 2018, pp. 95-119.

Bevilacqua P., De Clementi A., Franzina E. (a cura di), Storia dell'emigrazione italiana, vol. I, Partenze, Roma, Donzelli, 2001

Bevilacqua P., De Clementi A., Franzina E. (a cura di), Storia dell'emigrazione italiana, Vol. II Arrivi, Roma, Donzelli, 2002.

BoccA G., Gli italiani sono razzisti?, Garzanti, Milano 1988.

BoNDI A., «Più stranieri più criminalità: un'equazione che non torna», in LibertàCivili, fascicolo 6, 2010, pp. 115-120.

BonINI D., «Politica immigratoria e bisogni sociali dell'immigrato. Una prima riflessione», in N. Sergi (a cura di), L’immigrazione straniera in Italia, Edizioni Lavoro, Roma, 1987.

BoNTEMPELLI S., «Il governo dell'immigrazione in Italia: il caso dei «decreti flussi», in P. Consorti, Tutela dei diritti dei migranti, Pisa, Plus, 2009, pp. 115-136.

BonTEMPELLI S., «Da "clandestini” a "falsi profughi”. Migrazioni forzate e politiche migratorie italiane dopo le primavere arabe», in Meridiana, 86, 2016, pp. 167-79.

Brouwer E, Digital Borders and Real Rights. Effective Remedies for ThirdCountry nationals in the Schengen Information System, M. Nijhoff Publisher, Leiden-Boston 2008.

CACCAvo R., «Il lavoro straniero nelle strategie sindacali italiane», in Studi Emigrazione, 138, 2000, pp. 247-279.

Calvanese F., L'Italia tra emigrazione e immigrazione, Roma. Filef, 2000.

CAmpani G., Dalle minoranze agli immigrati. La questione del pluralismo culturale e religioso in Italia, Unicopli, Milano, 2008.

Casacchia O., Natale L., Strozza S., «Migrazioni interne e migrazioni internazionali: il nuovo ruolo del Mezzogiorno nel sistema migratorio nazionale», in C. Bonifaci (a cura di) Mezzogiorno e migrazioni interne, Cnr-Irp Monografie, 10, 1999, pp. 237-272.

CAva A., «L'immigrato immaginato. Racconti mediali a confronto», in Quaderni di intercultura, anno III, 2011, pp. 1-14.

CHECCO A., «L'emigrazione siciliana, i luoghi e le comunità di partenza (18811913): una proposta di ricerca», in Giornale di storia contemporanea, 2 , 2000, pp. 109-147.

ChIARA L., La modernizzazione senza sviluppo. Messina a cento anno dal terremoto (1908-2008), Le Lettere, Firenze, 2011. 
Immigration in Italy between First and Second Republic. From the Reception Policies...

ChIARA L., «La Sicilia e la modernizzazione incompiuta (1880-1960)», in L. Chiara, L. D’Andrea, M. Limosani (a cura di), La Sicilia nel secolo breve. Modernità e sottosviluppo, Giuffrè, Milano, 2013.

ChIARA L., Frisone F., «Immigrazione ed emigrazione in Italia. Profili storici», in G. Moschella, L. Buscema (a cura di), Immigrazione e condizione giuridica dello straniero, Aracne, Roma, 2016, pp. 41-65.

ChiARomonte W., Lavoro e diritti sociali degli stranieri: il governo delle migrazioni economiche in Italia e Europa, Giappichelli, Torino, 2013.

Colarizi S., Gervasoni M., La Tela di Penelope. Storia della Seconda Repubblica, Laterza, Roma-Bari 2012.

Collinson S., Le migrazioni internazionali e l'Europa, Il Mulino, Bologna, 1994

Colombo A., Sciortino G., «Italian immigration: the origins, nature and evolution of Italy's migratory systems», in Journal of Modern Italian Studies, 9, 2004, pp. 49-70.

Colombo A., Sciortino G., «Introduzione», in Idd. (a cura di) Stranieri in Italia. Trent'anni dopo, il Mulino, Bologna 2008.

Colucci M., «Per una storia del governo dell'immigrazione straniera in Italia: dagli anni sessanta alla crisi delle politiche», in Meridiana, 91, 2018, pp. 9-36.

Corti P., «L'emigrazione temporanea in Europa, in Africa e nel Levante», in P. Bevilacqua, A. De Clementi, E. Franzina (a cura di), Storia dell'emigrazione italiana, Vol. I, Partenze, Roma, Donzelli, 2001, pp. 113-228.

Cusumano A., Il ritorno infelice: $i$ tunisini in Sicilia, Sellerio, Palermo, 1976.

D’Angelo M., Comunità straniere a Messina tra XVIII e XIX secolo, alle origini del British Cemetery, Perna, Messina, 1995.

Der Wal J., «Il linguaggio del pregiudizio etnico», in Politica ed Economia, XXIII, 1991, pp. 33-48.

EINAUDI L., Le politiche dell'immigrazione in Italia dall'Unità ad oggi, Editori Laterza, Roma Bari, 2007.

FRANZINA E., «"Il Biometro delle nazioni”: primi rilevamenti sull'emigrazione», in Quaderni storici, 45, 1980, pp. 966-1005.

FRIDEgOTTO M., L'Accordo di Schengen: riflessi internazionali e interni per l'Italia, Franco Angeli, Milano 1992.

Gargiulo E., «Una filosofia della sicurezza e dell'ordine. Il governo dell'immigrazione secondo Marco Minniti», in Meridiana, 91, 2018, pp. 151-173.

GERMANI A., «Immigrazione: il modello mediterraneo», in Affari sociali ed Internazionali, 4, 2001, pp. 107-115.

Ginsborg P., L'Italia del tempo presente. Famiglia, società civile, Stato, 19801996, Einaudi, Torino, 1998.

GRANDE E., «Mediterraneo, bacino di migrazioni», in Affari sociali internazionali, 1, 2003, pp. 67-80. 
Luigi Chiara, Francesca Frisone

Hatton T.J., Williamson G. (ed.), Migration and the International Labour Market, 1850-1939, Routledge, London 1994.

HeIn C. (ED.), Rifugiati, vent'anni di storia del diritto di asilo in Italia, Donzelli editore, Roma, 2010.

LEE E. S.,«A Theory of Migration», in Demography, Vol. 3, n. 1. (1966), pp. 47-57.

LORETO F., «Sindacati e immigrazione straniera in Italia dalla fine degli anni settanta ai primi anni novanta», in Meridiana, 91, 2018, pp. 77-93.

Madonia M., Il fenomeno migratorio dei tunisini nel Mazarese, Pontificia Università Lateranense, Tesi non pubblicata, Roma 1975.

Mai N., «Miths and Moral Panics: identity and the media Representation of Albanian Immigration», in R. Grillo, J. Pratti (ed.), The Politics of Recognizing differences: multiculturalism Italian Style, Ashgate, Aldershot, 2002, pp. 77-94.

MAYDA A. M., International Migration: a panel data analysis of the determinants of bilateral flows, in CReAM Discussion Paper Series, n. 7, April 2007, Centre for Research and Analysis of Migration (CReAM), Department of Economics, University College London, pp. 1-35.

MARChETTI C., «Rifugiati e migranti forzati in Italia: il pendolo tra "emergenza" e "sistema"», in REMHU: Revista Interdisciplinar da Mobilidade Humana, 22, 2014, pp. 53-70.

Meny Y., Surel Y., Populismo e democrazia, Il Mulino, Roma-Bologna 2001.

Molina S., Atlante delle migrazioni: Storia, materiale realizzato da Fieri nell'ambito del progetto «Oltre le migrazioni» condotto da CISV, FIERI e Il Nostro Pianeta, con un contributo della Compagnia di San Paolo, 2011.

MontAnARi A., «La geografia del brain drain. Il caso dell'Italia nel contesto internazionale», in Rivista Geografica italiana, anno C, 1993.

NovARESE D., «Tra Inghilterra e Francia. Dichiarazione e garanzia dei diritti fondamentali nel costituzionalismo europeo fra sette e ottocento,» in Società $e$ storia, 99, 2003, pp. 31-44.

Ostuni M.R., Rosoli G., «Saggio di bibliografia statistica dell'emigrazione italiana», in G. Rosoli (a cura di), Un secolo di emigrazione italiana 18761976, Roma, 1978, pp. 273-342.

Palomba R., Righi A., Quel giorno che gli albanesi invasero l'Italia....: gli atteggiamenti dell'opinione pubblica e della stampa italiana sulla questione delle migrazioni dall'Albania, Roma IRP, 1993.

PAOLI S., «La legge Turco-Napolitano: un lasciapassare per l'Europa», in Meridiana, 91, 2018, pp. 121-148.

PUGLIESE E., L'Italia tra migrazioni internazionali e migrazioni interne, Il Mulino, Bologna, 2002.

RAFFAELE S., «Rapporti migratori e criminalità nella prospettiva dell'integrazione e della sicurezza sociale», in F. Astone, A. Lupo, V. prudente, A. Romeo (ed.), I diritti sociali al tempo delle migrazioni, Editoriale scientifica, Roma 2019, pp. 55-75. 
Immigration in Italy between First and Second Republic. From the Reception Policies...

Ravenstein, E. G., «The Laws of migration», in Journal of the Royal Statistical Society, XLVIII, Part 2, June 1885, pp. 167-227.

Revelli M., Populismo 2.0, Einaudi editore, Torino, 2017.

Ricotтi C.R., Il costituzionalismo britannico nel Mediterraneo (1794-1818), Giuffré editore, Milano, 2005.

RiNAURO S., «Le statistiche ufficiali dell'emigrazione italiana tra propaganda politica e inafferrabilità dei flussi», in Quaderni storici, n. 2, 2010, pp. 393-417.

Rosselli J., Lord William Bentick e l'occupazione della Sicilia 1811-1814, a cura di M. D’Angelo, Sellerio, Palermo 2002.

Salvemini B., «Note sul concetto di Ottocento meridionale», in Società e Storia, 26, 1984, pp. 917-945.

Sbraccia A., SaITTA P., Lavoro, Identità e Segregazione dei Tunisini a Mazara Del Vallo (Work, Identity, and Segregation of the Tunisians in Mazara Del Vallo), Occasional Papers No. 9, Cespi, Roma, 2003.

Sciortino G., Colombo A., «The flows and the flood: the public discourse on immigration in Italy, 1969-2001, in Journal of Modern Italian Studies, 9, 2004, pp. 94-113.

SORI E., «Il lavoro globalizzato, L'Emigrazione intercontinentale europea (18001914)», in Memoria e Ricerca, 14, 2003, pp. 99-158.

SpARschuH O., «Citizens and non-Citizens: the relevance of Citizenship status in Labour Migration within Italy and to Germany from 1950s to 1970 s», in Journal of Contemporary History, 49, 2014, pp. 28-53.

Tonini A., «La questione migratoria e il principio di libera circolazione nell'Unione Europea: una difficile armonizzazione», in Meridiana, 93, 2010, pp. 283-302.

VENTURINI A., Le migrazioni e i paesi sudeuropei. Un'analisi economica, UTET, Torino, 2001.

VILlANI P. (A CURA DI), Trasformazioni delle società rurali nei paesi dell'Europa occidentale e mediterranea (secolo XIX-XX): bilancio degli studi e delle prospettive di ricerca, Atti del Congresso internazionale svoltosi a Napoli e Sorrento dal 25 al 28 ottobre 1982, Napoli, Guida, 1986.

Vitiello M., «Il modello mediterraneo delle politiche migratorie: le politiche di ingresso e di stabilizzazione», in E. Pugliese, G. Ponzini (a cura di), Un sistema di welfare mediterraneo, Donzelli, Roma, 2008, pp. 287-311.

ZIRULIA S., «I respingimenti nel Mediterraneo tra diritto del mare e diritti fondamentali», in AIC, 2, 2012, pp. 1-11.

Zolberg A., «A matter of State. Theorizing Immigration Policy», in C. Hirschman, P. Kasinitz and J. De Win (ed.), The Handbook of International Migration, Russel Sage Foundation, New York, 1999. 


\section{Notes on contributor}

Luigi Chiara is Associated Professor of Contemporary History in the University of Messina-Department of Political and Juridical Sciences. He is also vice-director of the Department. He wrote many papers and books, some focused on the History of the South-Italy.

Francesca Frisone is research fellow at the Chair of Contemporary History, University of Messina, Department of Political and Juridical Sciences. She received the Ph.D. in History and Comparison of European Political and Juridical Institutions in the same Department. She wrote the book "La formazione dei Parlamenti siciliani nel periodo della transizione costituzionale (1810-1815)». ffrisone@unime.it 